\title{
Luzes a quem está nas trevas: a linguagem política radical nos primórdios do Império*
}

\section{Marcello Basile}

Wem suas vertentes diversas, vem passando por um acentuado processo de renovação, marcado pelo estreito contato travado com outras disciplinas e outros campos do conhecimento histórico, particularmente com a chamada nova história política, a história cultural e a crítica literária. Novas abordagens buscam, então, ir além das tradicionais análises limitadas à exposição das idéias de um autor isoladamente ou de toda uma corrente de pensamento (cujas obras são tidas como dotadas de um significado intrínseco, dado pelo autor ou conformado a um determinado estilo), geralmente vinculadas a um contexto social que mecanicamente determinaria a produção e a recepção (esta, reduzida às influências) das idéias. Observase, assim, uma atenção crescente por temas e questôes antes praticamente ignorados, como a apropriação e a circulação social das idéias, os mecanismos de mediação e de vulgarização das grandes obras, a literatura marginal e de circunstância, os pasquins e panfletos, os recursos de argumentação retórica e a linguagem política. ${ }^{1}$

Interessa aqui destacar este último campo de estudo, cujos avanços são em grande parte devidos aos trabalhos de John Pocock e de Quentin Skinner. Ambos têm se dedicado ao estudo do pensamento político moderno na Europa, tendo como base a análise da linguagem e do vocabulário político que constituem as matrizes sócio-intelectuais e os fundamentos ideológicos dos textos de natureza política e filosófica produzidos no período. De acordo com os dois autores, a linguagem normativa disponí-

* Este artigo é baseado no capítulo IV de minha Dissertação de Mestrado, intitulada Anarquistas, rusguentos e demagogos: os liberais exaltados e a formação da esfera pública na Corte imperial (1829-1834). Rio de Janeiro: Programa de Pós-Graduação em História Social da UFRJ, 2000.

Topoi, Rio de Janeiro, set. 2001, pp. 91-130. 
vel, expressa em termos de um vocabulário próprio, configura-se como um elemento fundamental no estabelecimento, na definição e na resolução das principais questôes problematizadas em uma dada época; contribui para determinar os parâmetros de discussão, ao mesmo tempo em que fornece um elenco de possibilidades de escolha para aqueles que pretendem expressar e legitimar suas idéias e condutas (ou contestar e denegrir as de outrem), constituindo-se, então, em um fator determinante das ações praticadas pelos agentes sociais envolvidos no debate político. Texto e contexto articulamse, assim, de maneira interligada, definindo a linguagem como produto e como agente da história, sem com isso recair no determinismo contextual da tradicional história das idéias ou nas posições radicais introduzidas, na esteira da crítica literária, pela chamada virada lingüistica, que reduzem tudo à linguagem ou ao texto. ${ }^{2}$

No Brasil, há uma significativa concentração de trabalhos entre as décadas de 1950 e 1970, circunscritos, todavia, aos quadros da antiga história das idéias; os avanços operados na área ainda se acham muito pouco problematizados, sendo as novas abordagens incorporadas "de maneira um tanto informal e fragmentada”, conforme salientou, em balanço historiográfico recente, José Murilo de Carvalho. ${ }^{3}$ Há, assim, um vasto e promissor campo a ser explorado, inclusive no que diz respeito às linguagens políticas diversas que informavam os projetos produzidos em momentos cruciais da história política brasileira.

\section{Os liberais exaltados e o surgimento de uma linguagem política radical}

O espaço de tempo que acompanhou e se seguiu à Independência do Brasil destaca-se como um período-chave para o estudo do desenvolvimento das linguagens políticas. Entre 1820 e 1822, o movimento vintista português tornou-se responsável por uma inédita divulgação no Brasil das idéias liberais, embaladas pela grande proliferação de jornais e panfletos que passaram então a ser produzidos e circulavam nos dois lados do Atlântico, formando uma densa rede de debates. Uma cultura política liberal desenvolve-se, assim, em torno dos sucessivos acontecimentos desencadeados nos dois países, bem como em torno de questôes como o constitucionalismo 
monárquico, representação, divisão de poderes, pacto social, soberania da nação, direitos do cidadão e liberdade, opondo-se a tudo aquilo que se relacionava com o governo absoluto. Uma linguagem política peculiar emerge neste debate, veiculada nos periódicos e, sobretudo, nos panfletos, que se encarregavam, assim, de difundir o novo vocabulário político, nos termos colocados por aquelas questões. Mas esta cultura política, e logo a linguagem de que se revestia, encontravam-se essencialmente fundamentadas nas mitigadas Luzes portuguesas, o que explica os limites de seus mais caros valores, como a união entre monarquia constitucional e Igreja católica, uma visão de mundo embaraçada na doutrina cristã, e uma liberdade e igualdade restritas ao plano da lei. Substancialmente, portanto, não incorporavam os princípios mais radicais da Ilustração francesa ou mesmo do Liberalismo americano; daí as bases moderadas da Independência. ${ }^{4}$

Uma linguagem radical só irá desenvolver-se propriamente a partir dos últimos anos do Primeiro Reinado, com a emergência de uma nova facção política, os liberais exaltados. É certo que, antes disso, alguns de seus postulados já eram professados por Cipriano Barata, redator da célebre Sentinella da Liberdade, publicada sucessivamente em Pernambuco, na Bahia e no Rio de Janeiro entre 1823 e 1835 (redigida inclusive dentro das diversas prisóes por onde passou $)^{5}$. Mas foi somente com a organização dos liberais exaltados (dos quais o próprio Barata se tornaria um líder nacional) que os princípios do Liberalismo radical se articulariam em um projeto, não mais de um homem, e sim de todo um grupo político.

O surgimento dos exaltados se dá em meio à crise política que desde 1826 vinha se abatendo, de forma mais sistemática, sobre o governo de Pedro I, com a reabertura do Parlamento e o revigoramento da Imprensa política, após os anos de chumbo que se seguiram à Independência. Nestas duas instâncias se concentraram as forças de oposição ao Imperador, a princípio capitaneadas por um grupo de liberais moderados, composto por uma nova geração de políticos do Rio de Janeiro, Minas Gerais e São Paulo, ligados à produção e ao comércio de abastecimento da Corte, dentre os quais se destacavam homens como Evaristo da Veiga, Bernardo Pereira de Vasconcellos e Diogo Feijó. ${ }^{6}$ Pretendia este grupo realizar reformas de caráter estritamente político-institucional, que limitassem os poderes do Im- 
perador, conferissem maiores prerrogativas à Câmara dos Deputados e autonomia ao Judiciário, assegurassem a aplicação das conquistas liberais já firmadas ou previstas pela Constituição (sobretudo no que concerne aos direitos civis dos cidadãos) e, ao mesmo tempo, estabelecessem uma liberdade circunscrita à esfera da lei e da ordem.

Por volta de 1829, no entanto, com a radicalização das lutas políticas, frente a insistência de dom Pedro em não ceder aos clamores liberais, persistindo em sua marcha autoritária de governo, um grupo com discursos, propostas e ações mais ousados começa a se articular na corte e em várias províncias. A crítica agora ia além das reformas político-institucionais pleiteadas pelos moderados, avançando, não só neste campo, mas também sobre delicadas questões sociais até então deixadas de lado. Para começar, defendiam o regime republicano, o sistema federalista, a separação entre Igreja e Estado, assim como a reforma agrária, uma cidadania isenta de qualificações excludentes de renda, instrução, sexo ou etnia, o fim gradual da escravidão, a melhoria das condiçôes de vida das camadas de baixa condição social, uma igualdade não apenas jurídica, mas também social, a soberania do povo e, como recurso extremo para a realização destes fins, uma revolução popular. ${ }^{7}$ Ao contrário dos moderados, a nova facção não surge como uma coalizão parlamentar, onde, aliás, nunca viria a ter representação substancial. Seus membros tampouco integravam as elites política ou socioeconômica do Império, sendo basicamente oriundos das camadas médias urbanas; eram profissionais liberais, funcionários públicos, militares, pequenos e médios comerciantes, a exemplo do boticário Ezequiel Corrêa dos Santos, do padre e professor Marcelino Pinto Ribeiro Duarte, dos majores Miguel de Frias e Vasconcellos e Antonio Rangel de Vasconcellos, do tipógrafo Francisco de Paula Brito, e dos jornalistas Antonio Borges da Fonseca, Cipriano Barata e João Baptista de Queiroz. É, portanto, no âmbito da esfera pública em gestação que despontariam os exaltados, fazendo da imprensa e das ruas seus principais canais de atuação política. ${ }^{8}$

Apesar das acentuadas divergências ideológicas e de alguns inevitáveis desentendimentos ocorridos entre os dois grupos, moderados e exaltados formaram um bloco de oposição ao governo de Pedro I, mantendo-se 
unidos, em face do inimigo comum, até a queda do imperador, a 7 de abril de 1831. Todavia, com a instauração da Regência, a subida dos moderados ao poder, mais bem estruturados politicamente, e o conseqüente alijamento dos exaltados logo provocaram o rompimento da aliança liberal, fazendo com que estes últimos radicalizassem ainda mais suas posições, agora no combate ao governo regencial. Nisto estarão acompanhados de uma terceira facção política, surgida pouco depois da Abdicação — os caramurus - , defensores de um modelo de governo autoritário e conservador, em alguns casos (não na maioria das vezes) de cunho restaurador, nos moldes vigentes no Primeiro Reinado. Embora não houvesse qualquer afinidade ideológica entre os dois grupos, uma ala dos exaltados uniu-se então aos caramurus, no intuito de formar um bloco de oposição à Regência moderada, compondo aquilo que Evaristo da Veiga chamou de "liga de matérias repugnantes"; ' outra ala, porém, buscou uma aproximação tática com os moderados, a fim de obter no Parlamento a aprovação das reformas constitucionais (consubstanciadas, em 1834, no Ato Adicional) que eram obstaculizadas no Senado pela bancada caramuru, ao passo que um terceiro segmento exaltado preferiu não fazer qualquer tipo de composição com seus rivais. Percebe-se, assim, que os exaltados não chegavam a constituir um grupo bem homogêneo, mas o mesmo é válido, sem dúvida, para as demais facções, que também conviviam com suas divisões internas e princípios conflitantes.

O fato é que os exaltados tornaram-se os introdutores no Brasil imperial de uma nova linguagem política, pautada fundamentalmente nos princípios do jacobinismo francês. E o principal responsável, na capital, pela difusão desse vocabulário radical foi o mais importante jornal exaltado da corte, a Nova Luz Brasileira, que circulou ininterruptamente entre 1829 e 1831, em um total de cento e oitenta números regulares, redigidos por Ezequiel Corrêa dos Santos, com a eventual colaboração de João Baptista de Queiroz. Coube a este jornal a iniciativa singular de lançar, ao longo de quarenta e nove ediçôes (do no 11 ao 59, publicados de 15 de janeiro a 13 de julho de 1830), o que poderia ser chamado, dado o caráter da empresa, de um dicionário cívico doutrinário, composto por nada menos que cento e oito conceitos (ou definiçôes, como foram então denominados) de significação política. Embora não esgote o ideário exaltado, trata-se, por certo, 
de um riquíssimo manancial da linguagem e do vocabulário político que informavam o pensamento e a ação dos exaltados, merecendo, portanto, uma análise detalhada.

\section{O dicionário cívico doutrinário da Nova Luz Brasileira}

De um modo geral, os conceitos formulados no dicionário cívico doutrinário da Nova Luz Brasileira definem-se em torno da oposição semântica entre despotismo e liberalismo. A partir deste referencial, estruturam-se diversos eixos temáticos, onde se pode bem perceber a originalidade de conteúdo e a abrangência do campo conceitual exaltado. A título de comparação, serão eventualmente mencionadas as definições encontradas na $2^{\underline{a}}$ edição (de 1813) do Diccionario da lingua portugueza, de Moraes Silva, o mais conhecido na época, para aqueles vocábulos também apresentados pelo periódico em questão. A crítica por este feita ao poder absoluto e a apologia ao governo liberal já se evidenciam nas definições que tratam da forma de governo. É o caso, por um lado, de Governo Absoluto, Rei Absoluto, Despotismo, Arbitrio ou Arbitrariedade, Tirania, Tirano, Direito de Força, O Maior Crime do Cidadão, Poder Real e Pessoa Sagrada e Inviolável; e, por outro, de Governo Misto, Popular ou Monarquia Liberal, Governo Legitimo (que dá nome a dois "verbetes"), Governo Livre, A Melhor Forma de Governo e Legitimidade.

Em relação ao primeiro grupo, observa-se que Governo Absoluto é definido como "todo aquele governo, que reúne os poderes em uma única pessoa, e que por isso nele pode mais a vontade de um só homem, e de qualquer que obre em seu nome, do que as leis; porque ainda que estas existam, não são mais do que meros formulários”. Por sua vez, Rei Absoluto é "aquele que usurpa os Poderes da Nação, e por isso está continuamente em estado de guerra com o povo". Já o Despotismo é "uma ação fora das Leis" e "procede do abuso do poder", assim como Arbitrio ou Arbitrarieda$d e$, isto é, o "quero porque quero, porque assim é minha vontade sem freio, e não faço caso das Leis". ${ }^{10}$ A Tirania é "a anarquia dos que governam, pois nela não há Leis" e "anda unida com a usurpação do Poder", sendo Tirano aquele que "viola, profana e pisa as Leis sociais; aquele que usurpa a auto- 
ridade que não lhe pertence, e ataca os direitos dos Cidadãos e os oprime". Da mesma forma, Direito de Força é "o pretendido direito do ladrão sobre as coisas que ele rouba", sendo este o caso de quem "usurpa um governo livre". Nesta perspectiva, O Maior Crime do Cidadão é "o arrojo, e atrevimento de querer humilhar a sua Pátria, e fazer escravos seus Concidadãos, usurpando os Poderes, e fazendo-se Senhor absoluto". Bem reveladora é, ainda, a definição de Poder Real, "invenção moderna dos Reis déspotas", para "enganar os Povos; e para ensinar, que os reis devem imperar com o seu poder pessoal, e privativo sobre as Assembléias, a fim de disporem dos três poderes, e dos direitos todos da Sociedade". Completando o quadro, Pessoa Sagrada e Inviolável, que se desdobra em duas outras, ${ }^{11}$ é aquela que "só dá conta de suas açôes a Deus", estando "fora do alcance das Leis da Sociedade", assim "recaindo todo o mal, e toda a responsabilidade sobre os ministros". ${ }^{12}$

Quanto ao segundo grupo, verifica-se, por outro lado, que Governo Misto, Popular ou Monarquia Liberal é aquele que "tem poderes divididos; que se dirige por meio de uma Constituição, que dá ao povo representação, influência, e parte em os negócios públicos, de tal modo que o governo por um lado é Monárquico, e por outro é Republicano, sendo o seu Chefe Rei ou Imperador hereditário". Por sua vez, Governo Legítimo é “aquele que um Povo, como verdadeiro e único Soberano, escolhe e dá a si mesmo, independente de força e sedução; e o conserva por seu gosto"; ou, em outra definição do termo, o governo que só "está fundado na reta razão, justiça, e consentimento dos Povos; isto é, na Lei por eles feita”. Da mesma forma, Governo Livre é aquele que "existe por escolha e consentimento franco dos povos, e que se mantém sem força d'armas [...] só por meio de Leis justas; governo em que o Povo obra e tem parte na Legislação, e em toda a administração por meio de seus Representantes, livremente escolhidos; governo que está fundado nas Leis, da natureza; nos direitos do homem, na razão e eqüidade". Neste sentido, A Melhor Forma de Governo “é a Constitucional liberal", porque é aquela "em que se pode abusar menos do poder; aquela onde se vexa menos a Nação com tributos, e despotismo, e se faz justiça com brandura e inteireza; e onde se pode conhecer, e corrigir com mais facilidade os abusos desse poder, e prestar ao mesmo tempo socorros ao povo". E Legitimidade, por fim, é "um privilégio durador, mas 
condicional, que dão as Leis ou a vontade geral e livre do Povo, para o chefe de qualquer Nação gozar da direção dos negócios públicos”, só existindo realmente, portanto, no governo misto liberal. ${ }^{13}$

No conjunto dessas definições, a Nova Luz Brasileira ressalta, portanto, sua defesa do governo liberal, baseada nos princípios do constitucionalismo, da representatividade e do pacto social, e sua oposição intransigente ao governo absolutista, onde nada disso teria lugar, existindo apenas a vontade arbitrária do governante, acima de tudo e de todos. ${ }^{14}$ Até aí nada de singular ou de novo. O ponto importante a destacar é o que se refere à sustentação do chamado governo misto, ou seja, aquele que, imbuído das prerrogativas liberais, combinaria os princípios republicanos (no sentido aqui de bem público, da participação dos cidadãos na gestão da coisa pública) e monárquicos (a vitaliciedade, a hereditariedade do soberano). Um rápido esclarecimento faz-se, então, aqui necessário.

A aparente aceitação pelo jornal da Monarquia, enquanto regime de governo, deve ser compreendida dentro do contexto peculiar em que o dicionário foi produzido; isto é, ainda durante o Primeiro Reinado e, particularmente, no primeiro semestre de 1830, antes, portanto, do maior recrudescimento da oposição a dom Pedro, que se daria apenas a partir de setembro, com a chegada das notícias da revolução de 1830 na França, ${ }^{15}$ e de novembro, com o assassinato, em São Paulo, do jornalista Libero Badaró. Defender o regime republicano nesta época de fortes restriçôes à liberdade de exprimir idéias significava ser prontamente processado e preso por crime de imprensa, sob alegação de atentado contra a forma de governo e o imperante, conforme estabelecido nos artigos 3 e 4 da Constituição imperial. Por isso, não só a Nova Luz Brasileira, mas também todos os demais jornais exaltados, não tinham ainda condições de defender abertamente o regime republicano. Procuravam, assim, driblar a repressão governamental jogando, propositadamente de forma ambígua e com boa dose de retórica, com a dupla acepção da palavra república: aplicavam-na ora no sentido clássico do direito romano - como coisa pública (res publica), como organização política de um Estado, sob qualquer forma de governo, pautado pelo interesse público, pelo bem comum —, ora no sentido estrito de um regime específico de governo — no qual o mandatário é periodicamente 
eleito. Daí as usuais referências ao presidente dos Estados Unidos como monarca republicano e ao regime republicano como uma monarquia eletiva e temporária, como fazia a própria Nova Luz Brasileira, mais tarde, ao defender para o Brasil o que chamou de Monarquia Americana sui generis, ou seja, uma monarquia democrática, inspirada nas idéias de Silvestre Pinheiro Ferreira, que, além de constitucional, representativa e federalista, seria também não-hereditária e eletiva. ${ }^{16}$ As dissimulações do jornal não foram, contudo, suficientes para livrá-lo de um processo, movido em agosto de 1831 (já, portanto, em plena Regência), sob alegação de abuso da liberdade de imprensa, por comprometer a segurança pública, ao fazer apologia do regime republicano. ${ }^{17} \mathrm{~A}$ absolvição neste processo e a radicalização da luta contra o governo regencial após a revolta de julho de 1831, promovida pelos exaltados, devem ter encorajado o jornal, pois foi somente a partir daí que passou a abertamente assumir, juntamente com outros periódicos da mesma linha, o seu republicanismo, como fez ao demonstrar a um seu correspondente as pretendidas vantagens deste regime em relação à monarquia, justificando, assim, sua posição favorável à pronta instauração da República no Brasil:

É para não se aturar governos de ladrões que se inventou governo Republicano. Na República o que governa bem não ganha dez, ou doze mil cruzados por dia, como ganhava o Pedro traidor, fora o que ele roubava, e a corja que o cercava: é esta a primeira diferença. Além disto o que governa em governo Republicano é eleito como os Deputados: se governa bem, fica governando; mas se governa mal vai tratar de outro ofício: acontece como com os sapateiros remendōes, aos quais ninguém dá obra quando ele estraga a fazenda, que se lhe deu. Nas Repúblicas bem dirigidas castiga-se a quem governa mal; porém nas monarquias como a de Pedro traidor quanto mais sem vergonha, ladrão, e malvado é o rei, mais Auroras, Faróis, Januários, e Independentes ${ }^{[18]}$ aparecem para sustentarem o tirano, à sombra do qual os patifes fazem das suas. Só nas Repúblicas como a dos Estados Unidos é que se vê Justiça. Canais de navegação, Escolas, Hospitais \& c. em abundância para todos: é governo de que não gostam mal intencionados cangueiros, e comendadores. ${ }^{19}$

Voltando agora às definições do dicionário em questão, verifica-se que uma série de conceitos aborda os poderes e órgãos que constituem um 
governo liberal, sublinhando os princípios da divisão e independência dos poderes e da representatividade dos cidadãos. Assim, Gabinete, Ministério ou Governo é a "coleção dos Ministros d'Estado d'uma Nação, os quais dirigem todos os negócios conforme sua Constituição, tendo à frente o Rei, ou Presidente, como Chefe do Poder Executivo". Legislatura é o "Sublime Corpo Legislativo, isto é, a Assembléia Geral Nacional, considerada toda junta: às vezes consta só de Deputados; outras vezes tem duas Câmaras ou salas, uma de Deputados, outra de Senadores", durando o espaço de tempo entre cada eleição. Assembléia ou Representação Nacional é o "corpo unido dos Deputados, ou Representantes, ou Mandatários do Povo; (Procuradores) escolhidos, e eleitos livremente pelo mesmo Povo"; a assembléia poderia ser apenas Legislativa, quando "se ocupa em fazer as Leis civis e regulamentares, reformá-las, interpretá-las, e revogá-las: em zelar a Constituição”, ou também Constituinte, quando "lança os fundamentos do Contrato Social, e do Governo; é aquela que escolhe e aprova esse Governo, ou o muda e reforma, e dá estabilidade a todas as instituiçóes da Sociedade; arranja a Constituição - e tudo conforme os desejos e poderes concedidos e declarados livremente pelo mesmo Povo". Já Delegado são as "pessoas a quem o Povo confia certa porção de autoridade", enquanto Corpo Legislativo, Poder Legislativo e Representação Nacional são o mesmo que Assembléia Geral. Corpo Executivo ou Poder Executivo, por sua vez, é o "Chefe do Ministério (ou ele se chame Rei, Imperador, ou Presidente) com os Ministros d'Estado", ao passo que O Poder Judicial e O Corpo Judicial são os "Tribunais, e demais Magistrados que administram Justiça segundo as Leis". O jornal ensinava, ainda, que Maioria Geral significa "mais de metade dos votos do total dos votantes". ${ }^{20}$

Os significados de alguns desses conceitos podem parecer hoje um tanto óbvios e desnecessários, mas assim não eram vistos naquela época. Tais princípios só começaram a ser efetivamente divulgados no Brasil a partir do Vintismo e, em 1830, ainda eram uma realidade relativamente nova, sendo desconhecidos por boa parte da população, em particular aquela, de condição social mais modesta, que, embora alfabetizada, não tinha acesso à cultura erudita dos grandes tratados políticos e filosóficos, e mesmo aquela iletrada. Como será discutido adiante, eram especialmente esses segmen- 
tos que constituíam o público-alvo das folhas exaltadas; para eles, sobretudo, é que se dirigia um tal dicionário.

Sendo assim, a Nova Luz Brasileira ressaltava também que só sob governos liberais é que haveria, de fato, Estado, Nação e Pátria, e, logo, Patriotismo ou Amor da Pátria e Patriota, os quais seriam todos uma quimera nos governos absolutistas. Definindo Estado como "a forma de governo que a sociedade adota, e abraça para sua felicidade", explicava que o estado absoluto "só existe por engano e força", pois, "absorvendo todos os poderes, e sendo em benefício de uma só pessoa, e seus sequazes, não pode fazer a verdadeira felicidade do povo, a qual é o fim de todo o governo". Nesta perspectiva, a Primeira ou Suprema Lei do Estado só poderia ser "a salvação do Povo, e de seus direitos”, e, conseqüentemente, Nação era entendida como "o Povo reunido debaixo de um instituto, ou governo, conforme ao seu gosto, e circunstâncias". O conceito de Pátria é particularmente digno de nota. A princípio, afirma o jornal que há duas idéias de Pátria, uma física e outra moral. A primeira continha duas acepções, a geral e a particular, que apontam para a ambigüidade que a noção possuía na época: “a geral é a idéia de nação, ou província, a que o homem pertence; o particular, é a idéia da terra, cidade, vila, ou lugar, em que a natureza lhe deu o ser, e a vida”. Já a idéia moral remete à “obrigação, que tem a Pátria, de nos conservar os nossos direitos naturais, e civis, a respeito da vida, da liberdade, da igualdade, propriedade \& c.; de nos dar parte na administração do nosso governo; e de nos franquear os meios de perfeição pelas luzes do espírito; havendo a nossa existência sempre segura, agradável, e feliz". Neste sentido, ressaltava que "Extinta esta idéia moral, morrem as idéias físicas, e desaparece a idéia de Pátria". É por isso que nos governos absolutos "não há Pátria, porque falta a idéia moral, e por isso o homem torna-se escravo". Verifica-se, assim, na idéia física, a combinação de uma percepção nacional, regional e mesmo local de pátria, bastante comum no período, parecendo indicar a ausência de um verdadeiro sentimento de identidade nacional. ${ }^{21}$ Todavia, o que prevalece para o jornal é a idéia moral, que sublinha a perspectiva nacional de pátria, concebendo-a como a entidade que só pode ser a Nação - que deve garantir os direitos comuns dos cidadãos. Este mesmo sentido, vinculado ao sentimento de identidade nacio- 
nal, encontra-se presente na definição de Patriotismo ou Amor da Pátria, como um "sentimento elevado e sublime, que impele o Cidadão a procurar e promover o bem de sua Pátria, segundo as leis da eqüidade, sobre todos os bens do mundo; e a preferir esse bem a todos os seus interesses particulares; ainda mesmo que seja sacrificando a vida”. E não é outro o sentido de Patriota, "o homem livre, que ama a Pátria sobre todas as coisas, que a defende extremosamente, como corpo de que ele é parte". ${ }^{22}$

É claro que, para a Nova Luz Brasileira, os governos livres e ilustrados seriam a melhor evidência, na política, da Civilização, que nada mais era do que "o conhecimento e aplicação dos direitos naturais, e das gentes, pondo em prática bem clara os deveres da humanidade, e as virtudes sociais, que podem adoçar os costumes, e melhorar a sorte dos homens, e das Naçôes; tudo sobre as bases de um sistema universal de luzes, e boa moral". Este seria também o verdadeiro fim da Política, "ciência filha da verdade, para guiar freqüentemente os homens pelo caminho da prosperidade geral, e fazer o bem de todos dentro da sociedade civil, e fora dela, segunda as Leis da razão, justiça, e humanidade"; na concepção do jornal, os reis absolutos é que teriam transformado a política em uma "ciência de velhacaria, mentiras, enganos, e traições" ${ }^{23}$

Outro importante grupo de conceitos refere-se aos direitos e garantias inalienáveis do homem e do cidadão, onde se encontra melhor expresso o princípio do pacto social e das liberdades naturais, civis e políticas de que cada indivíduo deveria ser portador. Trata-se de um conjunto central de definições, uma vez que, como será visto depois, um dos principais objetivos, não só do dicionário, mas também da Nova Luz Brasileira, era conscientizar a população (livre) de sua condição de cidadão e, como tal, de seus direitos. Começava, assim, por explicar que Homem Socialé toda "criatura racional reunida em sociedade por sua livre vontade para ser feliz”, para, em seguida, sublinhar a importância desses direitos. Ensinava, então, que Incontestável são "os direitos do homem", isto é, "que o homem nasce livre e igual; que nasce para ser feliz neste mundo e na sociedade que ele contratou; e formou com os seus semelhantes: que deve viver seguro: [...] que só deve obedecer às leis justas: que deve destruir o despotismo: que deve ter o direito de votar, e ser votado”. Do mesmo modo, é tido como Inalienável 
"a Soberania do Povo, ou Nação; a liberdade, a igualdade total; o direito de votar, e ser votado nas eleições tendo virtudes e talentos". Já Imprescritivel é "a posse do território de um Povo; a Soberania nacional; o direito de conservar a vida, e a liberdade; o direito de escolher o governo, de o reformar, legislar". ${ }^{24}$

Antes de prosseguir na classificação e na discriminação desses direitos, convém, todavia, logo esclarecer a concepção bem peculiar de cidadania de que estava imbuída a Nova Luz Brasileira, manifesta já na primeira definição de seu dicionário, sem dúvida a mais original de todas: a do que entendia por Povo:

Falando em geral chama-se Povo à reunião de todos os habitantes que formam a sociedade, e habitam um país debaixo do mesmo governo. Nesta palavra Povo se compreende todos os indivíduos sem exceção, desde o Rei até o mais pobre, e miserável cidadão [...] entre nós não há mais do que povo, e escravos; e quem não é Povo, já se sabe que é cativo. Ora como entre o Povo de que se forma a sociedade civil, existem alguns homens mal criados, muito tolos, e cheios de vícios, e baixezas, os quais homens são algumas vezes madraços, e sem brio, e nem tratam de se instruir, e de abjurar sua grosseria, e maus costumes, assentou-se chamar plebe a esta gente má; e baixa plebe aos que d'entre a plebe, são incorrigíveis, e quase piores do que os maus escravos. Por conseqüência é baixa plebe o mau, e tolo fidalguete, ou negociante rico, ou alto empregado, cuja conduta, instrução, brios, e costumes são maus como acabamos de dizer. É pois ignorante ridículo, e insolente todo o parlapatão que em ar de Lord bagatela chama com desprezo - Povo à gente da sociedade que trabalha e produz riquezas com a enxada, ou com a enxó. Gente desprezivel é a que consome as riquezes [sic] que outros produzem, e em cima trata de resto ao verdadeiro cidadão produtor de riquezas; e para mais, só cuida em atraiçoar ao Povo, escravizando-o contra as ordens do próprio Deus, que quando fez Adão, não o fez Conde, Frade, ou Marquês. Quem diz = Povo = por desprezo é desprezível aristocrata [...] o governo deve emanar de todos, e pender de todos em massa; [...] e as Leis devem ser iguais para todos, e feitas por todos mediante seus Deputados, e só para o bem geral: donde também se conclui que só o merecimento e serviços a beneficio do país, podem dar distinção aos cidadãos enquanto vivem. Tudo o mais é violência despótica d'aristocratas velhacos, enquanto acham Povo tolo, e sem vergonha, que os não força a entrarem no caminho da justiça, e da Constituição. ${ }^{25}$ 
Verifica-se nesta concepção uma completa inversão semântica em relação ao que comumente se concebia na época como povo. Prova disso é a definição do termo dada pelo dicionário de Moraes Silva: "Os moradores da Cidade, Vila, ou lugar", "Nação, gente", "no fig. o que tem os costumes, usos, e credulidade do povo", assinalando, por fim, "Povo miúdo: a plebe, gentalha". ${ }^{26}$ Ainda mais esclarecedor era o que dizia a respeito o principal jornal moderado da Corte, a Aurora Fluminense, redigida pelo deputado Evaristo da Veiga:

Quando dizemos - povo - claro está que não falamos da massa ignorante, ou destituída de interesse na ordem social, que os demagogos adulam, e de que fazem o objeto de suas especulações; mas sim dos homens pensantes, honestos, e que nada tendo a ganhar na anarquia, olham todavia com justo receio para qualquer ensaio de despotismo, para qualquer aparência de menosprezo que se note a respeito da nação, do seu decoro, e prosperidade. ${ }^{27}$

Era uma clara alusão aos exaltados, os demagogos em questão. Mais do que isso, era a perfeita expressão da concepção corrente no Império, que distinguia povo e plebe, o primeiro restringindo-se apenas à boa sociedade, ao conjunto de homens bons organizados nos limites da ordem e dotados de liberdade, propriedade e educação, e a segunda referindo-se à massa desorganizada, propensa à desordem, pobre, ignorante e em condição de dependência. ${ }^{28}$ Bem diferente, portanto, era a concepção da Nova Luz Brasileira. Embora também fizesse uso da dicotomia povo e plebe, o sentido dado era totalmente inverso: quem ficava excluído da categoria povo e inserido na plebe não era a população subalterna, destituída de propriedade e instrução, mas sim os aristocratas, os ricos ociosos, que viviam à custa da exploração do trabalho alheio (claro que aí incluídos os grandes senhores de escravos e de terras). Todos os demais indivíduos livres, independentemente de quaisquer critérios de renda, instrução, sexo ou cor, constituiriam o povo e seriam, portanto, cidadãos, com plenos e iguais direitos civis e políticos. É bem verdade que a massa de escravos permanecia excluída do povo, mas, como meio paliativo para abrir a esses indivíduos o acesso à cidadania (o escravismo constituía um limite, mais matizado porém, tam- 
bém para o pensamento exaltado), a Nova Luz Brasileira propunha uma gradual extinção da escravidão, via libertação dos nascituros. ${ }^{29}$

De qualquer forma, trata-se de uma concepção bem abrangente e inovadora de cidadania, que é reiterada na definição de Cidadão, onde fica claro que seria digno deste "distintivo mais nobre do homem social", "toda a pessoa livre, homem ou mulher, que é parte de uma Nação livre, e que entra no seu contrato social, e participa de todos os atos e direitos políticos; e que por isso é uma porção da Soberania Nacional; em conseqüência do que tem voto em todas as eleições para as Assembléias, e pode ser eleito se tiver virtudes e talentos" ${ }^{30}$ Observa-se, em suma, que o estatuto pleno da cidadania deveria ser determinado e conferido basicamente em função da condição livre dos indivíduos, tendo estes, inclusive, o direito incondicional, não só de votar, como de ser votado, se dotados de virtudes e talentos; coisa que nada tinha a ver com os critérios excludentes de renda, sexo ou mesmo condição, prescritos na Constituição imperial (uma vez que, como se sabe, os libertos não podiam ser eleitores e tampouco eleitos, assim como não tinham qualquer direito de voto os homens com renda inferior a cem mil réis e as mulheres). ${ }^{31}$

Sobretudo ao admitir plenamente a mulher na cidadania política, a Nova Luz Brasileira ia além das práticas políticas até então vigentes, não só no Brasil, como em todo o mundo, inclusive durante a Revolução Francesa. Apesar de todo o discurso igualitário dos revolucionários, fixado na Declaração dos direitos do homem e do cidadão, e da intensa participação feminina nos clubes patrióticos, nas tribunas da Assembléia, na Imprensa, nas manifestações de rua e nas revoltas, as francesas não deixaram de ser situadas, segundo a célebre classificação de Sieyès, entre os cidadãos passivos, usufruindo apenas dos direitos civis, mas não dos políticos; e sua atuação no espaço público ainda foi sistematicamente cerceada. A grande maioria dos revolucionários (como Robespierre, Danton, Mirabeau e tantos outros) não chegou sequer a discutir o assunto, e os poucos que o fizeram foram quase sempre para atacar as aspiraçóes políticas femininas, entendendo, tal como Rousseau e outros ilustrados, que à mulher estavam destinados a família e o lar, pois não seria biológica, intelectual e moralmente capacitada a participar da vida pública; além disso, como e para que as 
mulheres iriam votar, já que, por definição, seriam dependentes e teriam as mesmas opiniōes de seus maridos? Quando muito, aceitavam que a mulher fizesse uso de seu papel educativo para, de acordo com as luzes da época, auxiliar na formação cívica de seus filhos, dos futuros cidadãos. Entre os homens, apenas Condorcet, Lequinio, Romme e Guyomar levantaram a voz para defender a igualdade de direitos entre os sexos, mas foram, quando não ignorados, combatidos com rigor. Olympe de Gouges chegou a produzir, em 1791, uma Declaração dos direitos da mulher e da cidadã, onde lembrava que, se a mulher tinha o direito de subir ao patíbulo, também deveria gozar dos direitos políticos; mas lhe custou caro a ousadia, e, ironicamente, acabou executada na guilhotina, como outras mulheres, durante o Terror. Como bem destacou Mary del Priori, no século das luzes, as mulheres permaneceram à sombra. ${ }^{32}$ Tanto que somente em 1944 as francesas obteriam direito de voto, enquanto inglesas, norte-americanas e brasileiras conquistariam o mesmo direito apenas um pouco mais cedo, em 1918, 1920 e 1934, respectivamente. No Brasil, os exaltados foram, portanto, o primeiro grupo político a defender sistematicamente a participação da mulher na esfera pública e a igualdade de direitos civis e políticos entre os sexos, tema que a Nova Luz Brasileira (tal como outros periódicos exaltados) abordou em diversas matérias, especialmente destinadas ao assunto. ${ }^{33}$

Além de definir esta sua original concepção de cidadania, a Nova Luz Brasileira prescrevia também, em seu dicionário, os direitos e as garantias inalienáveis do homem e do cidadão, salientando sua importância como parte fundamental do pacto social e como salvaguarda da liberdade dos indivíduos. Começava, assim, pela relação das Garantias:

a segurança da casa, e da pessoa do Cidadão, e da sua indústria, e propriedade: - O Direito de petição para qualquer pessoa poder queixar-se, e repelir o mal: - A faculdade de se ajuntarem os Cidadãos desarmados; para combinar os meios de promover algum bem, ou apartar algum vexame: - o poder falar livremente pela Imprensa, imprimindo, e publicando seus escritos: - o não ser preso, nem conservado em prisão, nem sentenciado senão conforme a Lei, e depois de certas formalidades: - e ser julgado pelo Tribunal do Júri, que é tribunal do Povo, e o único próprio a manter a segurança da vida, Liberdade, honra \& c: - o eleger livremente os Deputados 
à Assembléia, para afastar as maquinações e pretensōes do Poder: — o ter armas em sua casa para defender-se a si, sua Liberdade, Constituição e Pátria. $^{34}$

Estas garantias são desdobradas e especificadas em quatro tipos de direitos, nos termos da teoria liberal clássica. Os Direitos do Homem congregam todos os demais, abrangendo "os Direitos naturais; e os políticos, e civis que procedem dos naturais", sem os quais "o homem é escravo e não pode ser chamado homem”. Já os Direitos Naturais são “os efeitos da reunião das Leis, pelas quais Deus criou o homem tal qual ele é", compreendendo os direitos de "conservar e defender a vida, a liberdade, a igualdade, a propriedade, viver em sociedade, o exercício da indústria do corpo e do espírito, o esforço para adquirir instrução e luzes, a diligência para ser feliz, a escolha do governo e Religião, o estabelecimento do contrato social, a fatura e reforma das leis, a propagação da espécie, a resistência à opressão". Os Direitos Políticos, por sua vez, são "certos privilégios que o Cidadão deve ter, e tem infalivelmente em virtude das Leis fundamentais do Contrato social", referentes a "votar, e ser votado para Deputado, Senador, e quaisquer outros cargos da Sociedade tendo merecimentos e virtudes, reconhecer a necessidade dos tributos, em que se gastam, e o tempo que duram". E, por fim, os Direitos Civis, também resultantes das leis do pacto social, asseguram "andar o Cidadão seguro pelas ruas; não entrar ninguém em sua casa sem consentimento de seu dono; casar e viver seguro com sua mulher e seus filhos; gozar livremente de seus bens, e por morte reparti-los; fazer testamento; servir de tutor". ${ }^{35}$ A estas definições pode-se também acrescentar a de Propriedade, concebida, à maneira de Locke, em termos dos direitos naturais e civis: "Em sentido vulgar e errôneo [sic], são tão-somente os bens que o Cidadão adquire, e possui em terras, casas, dinheiro, e outras coisas que o valem. Porém a primeira propriedade do homem é a vida, a liberdade, e a igualdade; conjuntamente é a indústria, e forças de corpo e espírito, e sua mulher, e filhos". ${ }^{36}$

Cumpre notar, todavia, que, na visão da Nova Luz Brasileira, só haveria cidadania de fato nas sociedades regidas por um governo liberal. Nestas, o Súdito também é cidadão, entendido como "o nacional de um país que tem Constituição, ou governo misto liberal, isto é, governo com boas 
e bem mantidas garantias". Já onde impera a tirania e inexistem direitos constitucionais, o povo é reduzido a Vassalo ou, pior ainda, a Vassalo-Escravo. O primeiro seria "o nacional de um país que tem governo absoluto", acrescentando o jornal que havia apenas duas distinções entre o vassalo e o escravo: "1. que o vassalo hoje não é vendido como o escravo - 2. — que suposto pague muitos tributos desnecessários para o luxo do senhor e seus sequazes; contudo pode ter propriedade: mas apesar disto neste estado de vassalo a propriedade, a liberdade são superficiais e ilusórias, pois é um favor do senhor, e não um Direito". Já o segundo até vendido poderia ser, pois é "o pretendido vassalo em um governo puramente despótico; cuja ferocidade arbitrária anda mais descoberta, e pronta, e mais disposta a se desenfrear do que em o governo absoluto"; advertia, então, o jornal que entre o governo despótico e o absoluto a diferença era apenas de grau, chegando ambos a se confundirem: "até se pode dizer com verdade, que são irmãos. O rei absoluto é senhor, que absorve as leis à seu arbítrio, e tiraniza debaixo de fórmulas ordenadas por ele mesmo, e seus sequazes: o rei despótico, obra só por sua única vontade, sem essas fórmulas" ${ }^{37}$

A concepção exaltada de cidadania integra, portanto, ao menos em parte, as três vertentes clássicas da tradição democrática ocidental, cuja combinação acha-se no cerne do Liberalismo Radical. Está fortemente impregnada do humanismo cívico, enfatizando a preocupação com o interesse público, o bem coletivo, valorizando, então, a virtude cívica e o envolvimento direto dos cidadãos no governo da sociedade. Da mesma forma, está imbuída da visão comunitária, frisando o sentimento de pertencimento a uma comunidade (a nação), fomentando, assim, a identidade nacional. E está aí presente também o conceito liberal clássico de cidadania como titularidade de direitos, centrado na conquista das garantias individuais, em reação ao poder do Estado e às limitações legais e institucionais. ${ }^{38}$

Quanto a este último ponto, tomando como referência a classificação de T. H. Marshall para os direitos de cidadania, verifica-se que os direitos civis e políticos encontram-se perfeitamente presentes nas definições da Nova Luz Brasileira (os primeiros mesclados aos direitos naturais), mas faltam aí os direitos sociais, que, segundo Marshall, ainda não integravam 
o conceito de cidadania no século XIX. ${ }^{39}$ No caso em questão, todavia, esta ausência deve ser, no mínimo, relativizada, pois a preocupação sistemática com os problemas sociais, com a justiça social, era uma das principais características do pensamento exaltado, não encontrada em qualquer outro grupo político da época. Os exaltados partilhavam da crença de que a sociedade imperial era profundamente desigual e excludente, dividindo-se entre ricos e pobres, privilegiados e oprimidos. Como notou Emília Viotti da Costa, "Para os radicais deste período, a história é a história da luta entre os grandes e poderosos e o povo oprimido". ${ }^{40}$ Os exaltados não hesitaram em se colocar, então, ao lado dos pobres e oprimidos, lutando por uma sociedade mais justa e igualitária, por uma melhor distribuição das riquezas e pela incorporação desses segmentos à cidadania plena. Para eles, a liberdade só estaria realmente assegurada se acompanhada de uma certa igualdade, uma igualdade não apenas jurídica - como para os moderados, que seguiam os postulados clássicos do Liberalismo, na linha de Locke, Montesquieu e Guizot —, mas também social, segundo os preceitos democráticos, inspirados em Rousseau.

Dentro desta perspectiva é que se situam uma série de definições do dicionário que trabalham com aquela referida dicotomia social. A começar, por um lado, pelas de Mendigo ou Mendicante, Miserável e Pobre. O primeiro seria aquele que "pede esmolas, porque não pode trabalhar, nem ganhar nada com justa causa", ressaltando o jornal que "Mendigo também é Cidadão que pede os desvelos e piedade da Sociedade". O segundo, da mesma forma, seria aquele que "não pode bem suprir suas despesas e precisões com o que ganha; e por isso passa mal de sustento e vestuário, ficando até roto e sujo", sendo novamente frisado que o "miserável também é Cidadão e pede os cuidados da Sociedade". Quanto ao terceiro, seria aquele que "lucra com que manter com parcimônia a si, e à sua família; mas a quem não ficam restos para guardar", mais uma vez sendo assinalado que o "pobre é Cidadão como qualquer". ${ }^{41}$ Tais categorias não eram vistas aqui, portanto, sob a ótica preconceituosa da vadiagem e da criminalidade, típica do pensamento dominante sobre as classes perigosas; a condição em que estavam reduzidas era, antes, atribuída às desigualdades e às injustiças sociais. E mais do que dispensar a elas a piedade da filantropia iluminista, o discurso do jornal procurava dignificá-las, elevando-as ao rol da cidadania. 
Por outro lado, várias outras definições estão associadas às categorias sociais, às doutrinas e às instituições identificadas como portadoras de privilégios e defensoras do despotismo, como tal merecendo duras críticas do jornal. Em primeiro lugar, estão os conceitos diretamente ligados à postura profundamente antiaristocrática típica dos exaltados, oriunda daquele seu ideal igualitário. É o caso de Aristocracia, definida como a "classe da gente privilegiada, pela maior parte sem merecimentos nem virtudes: gente perigosa porque luta continuamente para sustentar o espírito de corporação e faz esforços para dominar a sociedade civil por meio de títulos vaidosos; e apossar-se de todas as terras, cargos, postos, dignidades, e honras, insultando e pisando o Povo". Já ficava aí patente a aversão da Nova Luz Brasileira aos privilégios, comendas, títulos de nobreza e, por extensão, aos detentores de tais distinçôes, ainda mais evidenciada na definição de Nobre ou Fidalgo, "espécie de senhor, d'alguma sorte feudal; ignorante, vadio, mal-fazejo, orgulhoso pelas obras de seus antepassados, e nada pelas suas próprias"; a isto acrescentava que "Toda a nobreza hereditária é peste da sociedade, por ser sequaz do governo absoluto, e do despotismo; é inimiga da liberdade, da igualdade, da justiça, e das boas leis sociais: toda ela é desprezadora do Povo, para o qual olha com desdém, e como para bestas de trabalho". A esta o jornal contrapunha a Nobreza Verdadeira, aquela "proveniente de grandes serviços feitos à Pátria unicamente, ou ao gênero humano”. A Nova Luz Brasileira defendia, assim, o fim de todos os títulos, condecorações e ordens honoríficas, que, segundo ela, introduziam distinções perniciosas entre os cidadãos. Havia ainda uma outra figura abjeta, que já teria desaparecido, mas nem por isso deixava de inspirar os nobres e senhores de engenhos brasileiros, o Senhor Feudal ou Encastelado, "fidalgo ignorantíssimo e brutal, que existiu antigamente; absoluto em suas terras e domínios, como qualquer Rei absoluto desses tempos de trevas, e de sangue; era déspota horrível, e tirano feroz em todo o sentido; seus vassalos eram verdadeiros escravos". 42

Esta ferrenha postura anti-aristocrática estendia-se também às instituições que permitiriam perpetuar a nobreza (e a concentração fundiária), como o Morgado, Marquesado, Condado, Ducado etc., que contavam com o "privilégio de não poderem ser vendidos, nem alienados, nem separados 
de qualquer modo que seja; e nem penhorados por dívidas, ainda que seus donos tenham usurpado o alheio; os quais bens tidos, pertencem a uma só família, passando ao filho mais velho por morte do pai, e ficando demais filhos deserdados contra as leis da natureza"; ainda segundo o jornal, os morgados "foram criados, e são conservados, para colunas do governo absoluto; eles são o açoite do bem comum, dos Cidadãos, e da liberdade das naçōes". ${ }^{43}$ A Nova Luz Brasileira introduzia aqui algumas das contundentes críticas à estrutura fundiária brasileira que seriam desenvolvidas mais tarde, quando da apresentação do seu Plano do Grande Fateusim Nacional, um polêmico projeto de reforma agrária, que propunha a distribuição geral de lotes de terra equivalentes às necessidades de subsistência e à capacidade de cultivo de cada cidadão, por meio do arrendamento das terras públicas devolutas e do confisco das propriedades particulares em situação ilegal, prevendo ainda a medição e a demarcação de todas as terras para efeito de cadastramento e confecção de mapas geodésicos. ${ }^{44}$

Tamanha era a prevenção do jornal com as classes privilegiadas que não livrava sequer aquelas que, embora abastadas, nada tinham de nobres ou aristocratas. Em sua visão, tais camadas contribuíam igualmente para a exploração e opressão da população subalterna, além de servirem de apoio ao governo absoluto. É o caso do Rico, "aquele que ganha abundantemente para se tratar com muitas larguezas, ficando-lhe ainda restos para guardar, e amontoar"; e o do Opulento, "aquele que além do que gasta, tem riquezas amontoadas, que reluzem e transbordam em todas as coisas, e por todas as partes". Incluído neste grupo, em vista dos serviços prestados ao despotismo, está também o Espião, "homem desprezível e infame", ou "demônio dissimulado, que vê, ouve, e espreita, para denunciar, ou contar a qualquer autoridade do Governo, por certo salário, que se lhe dá, ou por outro interesse". ${ }^{45}$

Resquício, talvez, de uma mentalidade de Antigo Regime, pautada na crença de que as redes de conspiração e intriga constituem um elemento fundamental da política, ou, quem sabe, mero artifício retórico, a Nova Luz Brasileira afirmava que espiōes estariam espalhados pelo país a serviço, não só do Governo imperial, mas também da extinta Santa Aliança (que, em sua opinião, ainda estaria em atividade!), dedicando-se secretamente a 
sustentar e promover os governos absolutistas em todo o mundo, inclusive no Brasil (onde contaria com o apoio dos corcundas, os seguidores de Pedro I). Dizia, assim, que a Santa Aliança era "uma sociedade moderna e perversa dos Reis absolutos", que, com o apoio do papa, estaria empenhada em "restabelecer e segurar o governo absoluto, com todo o seu antigo esplendor, e pô-lo em voga pelo mundo inteiro", buscando, com isso, "apagar as luzes do século, extinguir a liberdade da imprensa, e reduzir os homens a obedecerem cegamente, como brutos escravos, ao princípio monárquico, ou poder real, isto é, despótico". O suposto suporte ideológico desses governos também era atacado, o Maquiavelismo, "doutrina artificiosa e atraiçoada do perverso Maquiavel; a qual doutrina ensina a duplicidade, fingimento, engano, má fé, e traição, insinuada para conseguir as coisas com hipocrisia, quando se não podem obter facilmente: isto é, aconselhando a política dos reis absolutos". Todavia, apesar de todo o seu radicalismo, o jornal condenava o Sistema Regicida, "coleção e encadeação de doutrinas e máximas abomináveis, que provam e insinuam, que se devem matar os Reis quando forem tiranos". ${ }^{46}$

Ainda dentro desta linha de crítica aos sustentáculos políticos e sociais do Absolutismo, estão diversos conceitos que expressam o anticlericalismo exaltado, manifestação típica do Liberalismo Radical francês e inglês, mas, via de regra, estranho ao pensamento e à prática dos liberais brasileiros, que, a exemplo do Liberalismo ibérico, se distinguiam justamente por suas estreitas ligações com o clero. A própria Constituição imperial consagrava a união entre Igreja e Estado, estabelecendo o Catolicismo romano como religião oficial do Império. A Nova Luz Brasileira, porém, não via com bons olhos esta relação; acreditava ser o clero mais um segmento privilegiado e poderoso da sociedade, aliado dos reis e da nobreza na sustentação do despotismo. Algumas definições do dicionário expressam claramente esta visão, como a de Frades, "vagabundos de aspecto triste e dissimulado", "homens astutos, e fanáticos", que "pelejam com todas as armas visíveis; e invisíveis para usurpar a autoridade dos Reis, e os direitos das Nações; e conquistar este mundo". Piores ainda seriam os jesuítas, que integravam, segundo a definição de Sociedade de Jesus, Companhia de Jesus, Padres da Companhia ou Jesuitas, uma "sociedade de Frades abomináveis, 
eminentemente inimigos do sistema Constitucional”, que, além de acumular "grandes bens da fortuna por meio de pios enganos, e astuciosos furtos", também "plantam a árvore da estupidez, e apregoam com vários artifícios a pestífera obediência cega". ${ }^{47}$ Daí vinha o Jesuitismo (termo muito utilizado pelos exaltados como sinônimo de fanatismo, ortodoxia ou adesão ao despotismo), definido como a "prática das doutrinas e máximas infernais dos Jesuítas: máximas destruidoras da perfeição do espírito humano, e da liberdade; máximas opostas à verdadeira moral, e sagrados fins de Humana Sociedade". O ódio aos jesuítas chegava a ponto de, em mais uma inversão semântica, serem acusados de Ateu, entendido aqui como "aquele que não crê em Deus, e se persuade que a matéria, é que compõem [sic] o universo, e obra por si mesma”; haveria, então, ateu em teoria e ateu na prática: "o primeiro pode ser honesto e honrado Cidadão, e muito virtuoso; o segundo é sempre um monstro horrível, pelo fingimento com que se conduz em tudo: desta segunda classe foram, e são os Jesuitas". A crítica ao clero e seus costumes transparece, ainda, na definição de Celibatário, que "é o homem ou mulher, que vive sem se casar por sistema; ou instituição, ou corrupção de costumes, e que assim faz por interesse, ou fingimento". ${ }^{48}$

Com base nestes valores a Nova Luz Brasileira irá defender a realização de uma espécie de "reforma religiosa", onde, além da liberdade de consciência e de culto e a escolha de vigários e bispos por meio de eleições populares, preconizava a separação entre Igreja e Estado. É o que já sugeria na definição de Bula ou Breve do Papa, que, sendo só um "Decreto do Presidente e Chefe da Igreja Católica", "não tem nada de Santo, nem de divino; nem bento; e só pode recair sobre coisas, meramente da Igreja, e com aprovação do Povo, isto é, de sua Assembléia; e nunca sobre os poderes da Nação, e direitos dos Povos". Da mesma forma, a Concordata, enquanto uma "espécie de tratado, ajuste, ou convenção feita entre qualquer Governo e o Papa, sobre coisas que têm respeito à Religião", "não tem veneração particular, nem é coisa santa, ou benta”. E o mesmo se observa ainda na definição de Concílio, uma assembléia dos membros da Igreja Católica, "os quais todos são Representantes presumidos dos Povos; não para tratarem, nem levemente dos negócios políticos, e Direitos das nações; mas só para 
trabalharem sobre aquilo que diz respeito aos negócios de pura Religião”. ${ }^{49}$ Era esta uma clara reação ao ultramontanismo, doutrina católica antiliberal que pregava a infalibilidade do papa e a preeminência de sua autoridade sobre a dos governantes e a do clero dos países católicos, inclusive em assuntos temporais. Para a Nova Luz Brasileira, a Igreja corrompera-se ao se aliar ao Absolutismo, passando a intervir na soberania das naçóes livres. Fazia-se então necessário separar o Trono do Altar.

Um outro grupo de definições aborda o tema ainda obscuro das sociedades secretas. Algumas eram apontadas como organizaçôes de nível internacional que tramavam a favor do despotismo. É o caso dos Apostólicos de Espanha, "sociedade secreta perversa, a qual hoje está bem conhecida pelos seus manejos atrozes contra o sistema liberal", e cujo fim é "sufocar a liberdade, e igualdade, e todos os direitos do homem social; é apagar as luzes, que vão esclarecendo os Cidadãos; é destruir o andamento das Constituições, e a liberdade de imprensa; é acender o fogo do fanatismo, e furores da superstição"; segundo o jornal, esta associação seria parte integrante da Santa Aliança e se acharia espalhada por todo o mundo. No Brasil, mantinha ligações com o Apostolado, "Sociedade secreta perversa moderna, própria do Brasil, criada em 1822 para auxiliar os danados projetos dos absolutistas" e que é "a mesma chamada hoje dos colunas ou japônicos". Se as sociedades contrárias à liberdade dos povos eram criticadas, o mesmo acontecia com as que seguiam a doutrina regicida, como a Sociedade do Velho da Montanha, "sociedade terrível, que existiu antigamente, e há muito desapareceu", e que tinha como meta "vingar as injúrias da natureza, e matar os tiranos do Povo, especialmente os Reis e poderosos". ${ }^{50}$

Entretanto, a avaliação do jornal sobre as sociedades secretas era, em geral, positiva, vendo-as como um importante instrumento de luta contra os governos despóticos. Conforme esclareceu na definição de Sociedades Secretas em Geral, são "corporações bem fazejas, e virtuosas, que os Filósofos têm inventado para bem da humanidade; melhorando em particular, e ocultamente a triste sorte dos oprimidos mortais"; lembrava, contudo, que "também há sociedades secretas mal-fazejas, e abomináveis". O melhor exemplo do tipo de sociedade ilustrada era a Maçonaria ou Pedreiro Livre, "a mais santa de todas as associações reservadas", formada por "Cidadãos 
filósofos, e outras pessoas de luzes e virtudes", e que "trabalha dirigida por uma sua Constituição, espalhando luzes, e fazendo criar um certo espírito de união, amor e fraternidade”. Da mesma forma seriam os Iluminados, "associação muito pacífica e virtuosa", que "pelo nome bem mostra ser composta de homens de luzes, que iluminam a Sociedade Civil”. Também neste caso estava a sociedade dos Carbonários, "mui perseguida pela Santa Aliança, e Apostólicos, e pelo Papa", por pretender "reduzir à obediência das Leis, todos os déspotas e tiranos". Igualmente difamados pelos mesmos oponentes eram os Jardineiros, "acusados de quererem instruir os homens, e mudar os costumes das sociedades por meio de Constituições liberais, que apadrinhem eficazmente os direitos da espécie humana”. Os Niveladores, por fim, não foram esquecidos, com as duas máximas que os guiavam: "1. Que a Inglaterra não tem Constituição; e que só se governa por hábitos, opinião pública, e patriotismo; e que por isso é preciso fazer uma Constituição popular, verdadeira, o [sic] sólida: 2. Que uma revolução não é coisa dificultosa, nem perigosa" ${ }^{51}$

Sintonizada com o processo em curso de formação da esfera pública, a Nova Luz Brasileira entendia que as sociedades secretas seriam mais pertinentes sob os governos despóticos, onde o desrespeito às garantias políticas e civis impedia a sustentação de entidades livres. Onde o Estado liberal imperava, porém, a melhor forma de organização seriam as associações públicas, de cunho político e civil. É o que aponta na definição de Sociedades Patrióticas, que "trabalham a portas abertas; as quais Sociedades se formam com permissão dos governos livres", e "servem para socorrer os oprimidos, e desvalidos de toda a casta, contra a injustiça particular e pública, e para dar apoio às autoridades, e aos Escritores; e para animar a agricultura, comércio, artes, ciências, e navegação; e para vigiar dia e noite por toda a parte em benefício da Pátria”. Estas mesmas finalidades são destacadas em várias outras definições, onde se evidencia a importância então adquirida pela esfera pública. Uma delas é a de Espírito Público, "opinião geral, formada pelo conhecimento que o Povo tem de seus direitos, e dos princípios gerais, que estabelecem e conservam esses mesmos direitos", afigurando-se como condição para a liberdade. Sua expressão manifesta é a sempre enaltecida Opinião Pública, concebida como “o modo de pensar expresso, 
e uniforme de mais da metade de um Povo sobre qualquer objeto: daqui vem a influência, poder, e direção que dá a todos os negócios”. Mas para que a opinião pública pudesse efetivamente atuar, precisava contar, naturalmente, com a Salva-Guarda ou Escudo contra o Despotismo, isto é, a "liberdade da imprensa, publicando, censurando, e criticando os atos arbitrários do Governo, iluminando o Povo em seus direitos, e excitando a sua coragem”. A participação ativa dos cidadãos na política é, assim, mais uma vez sublinhada, sendo vista como O Meio Moral de Fazer a Felicidade da Pátria, ou seja, "o Cidadão ocupar-se dos negócios públicos, vigiar, e censurar continuamente os atos, ou ações do seu governo, a fim de que não se introduza pouco e pouco o despotismo". ${ }^{52}$

Chegamos, então, a um dos conceitos centrais do dicionário da Nova Luz Brasileira: o de Poder Soberano, Potência Soberana ou Soberania, assim definido pelo jornal:

significa o poder que se acha unido, e é inseparável do Povo, que compõem [sic] a massa da Nação; o qual Poder é uma entidade moral composta dos entendimentos, vontades, e forças particulares, e por conseqüência produzida pelos poderes de todos os Cidadãos; e esta entidade é que exprime a vida política da mesma Nação: por isso este Poder Soberano não se pode dividir, nem repartir, nem emprestar, nem dar, nem alienar por qualquer via, modo, ou maneira que seja. A Soberania, ou Poder Soberano, significa Poder que está acima de tudo; Poder sem igual. Este poder nasce da essência, ou substância inteira da Sociedade; [...] por isso a Soberania pertence unicamente à Nação inteira; isto é ao Povo: nenhum indivíduo, nenhuma família, pode ter o Poder Soberano como coisa sua própria. A palavra - Soberano - não se pode confundir com a palavra - Monarca. ${ }^{53}$

A idéia de que a soberania reside, não no governante ou mesmo no Parlamento, mas sim no povo, constitui um dos elementos-chave do pensamento exaltado, afigurando-se como um dos principais pontos de diferenciação para com os moderados. Estes postulavam a soberania da nação, entendendo, tal como Locke, que a soberania era a expressão da vontade da maioria, residindo, portanto, no Parlamento, já que o povo delegaria, por meio das eleições (censitárias), a soberania que a princípio detém aos seus representantes, encarregando-os de exercitá-la na prática. Já os exaltados, a exemplo da Nova Luz Brasileira, identificavam-se claramente, como 
visto, com o princípio democrático da soberania do povo, concebendo, nos termos de Rousseau, que, como expressão da vontade geral, a soberania residia no próprio conjunto do povo (entendido como a totalidade dos membros adultos da sociedade) e era, assim, inalienável e indivisível; com isso, o povo não se limitava a exercê-la apenas no momento das eleições (universais), e nem abria mão de sua soberania ao escolher seus representantes (que detinham somente um mandado formal da soberania), podendo, então, manifestá-la livre e diretamente quando assim desejasse (e não apenas, como em Locke, ao fim de cada legislatura ou, excepcionalmente, quando a lei da natureza e as regras do pacto social fossem rompidas). ${ }^{54}$ Esta ênfase no poder coletivo e soberano do povo é reafirmada em outra definição do dicionário, a de Poderoso: contra a idéia de que este seria "qualquer indivíduo, que tem grande representação na sociedade civil” ou "aquele que administra algum poder da sociedade diretamente”, o jornal afirmava que "o poder nasce das forças reunidas do Povo, que é o verdadeiro Poderoso". 55

É esta crença nos poderes supremos do povo que justifica outro elemento fundamental do pensamento e da ação política dos exaltados: a revolução popular, pregada insistentemente por todos os periódicos do grupo, inclusive a Nova Luz Brasileira. Diante de um governo despótico, que desrespeita as leis e os direitos dos cidadãos, configurando, assim, uma situação de quebra do contrato social, a revolução tornava-se, para os exaltados, não só um direito, mas até um dever de todo cidadão, enquanto parte do povo soberano. É este o sentido dado no dicionário à Insurreição, "justo levantamento do Povo contra os que atacam o contrato Social, e usurpam os direitos do mesmo Povo, ou da Nação", igualmente significando "justa revolução para destruir a tirania de um país, reformar, ou mudar o governo, se é vicioso e perverso"; advertia, porém, como que se defendendo das acusaçôes feitas aos exaltados, que "os sequazes do governo despótico usam da palavra - revolucionário, — como de uma injúria dirigida aos liberais; quando aliás, ela é honrosa: revolução não é motim, nem sedição", afirmava, sendo o revolucionário, portanto, aquele que "peleja a bem da ordem, e do bem comum da sua Pátria, e por isso é um Cidadão virtuoso". O jornal procurava, entretanto, distinguir insurreição de Rebelião, curiosamente 
definida como "a desobediência de qualquer pessoa ao Contrato Social, fazendo-se senhor do governo; é o ataque que os tiranos fazem às Leis fundamentais, abusando da força e confiança do Povo, para usurparem os poderes da Sociedade Civil"; e aqui, de novo, alertava para o uso perverso do termo pelos absolutistas, que "chamam rebelião ao ataque, e oposição que os bons Cidadãos fazem aos usurpadores”. O direito de resistência à tirania e opressão é ainda exposto em outras definições, como $O$ Princípio Fundador da Liberdade dos Povos, que nada mais é do que "a coragem e resolução dos Cidadãos em destruir o despotismo", visto que "a coragem heróica dos Cidadãos, é quem funda a liberdade, e lhe dá apoio fundamental". Da mesma forma, O Princípio Conservador, Fiador e Protetor da Liberdade e da Constituição vinha a ser " a coragem, e vigilância dos Cidadãos contra a ambição dos Chefes", considerando-se que "qualquer indivíduo tem o direito de se opor com as armas a quem acometer o contrato Social, e a liberdade, e lhe quiser substituir os seus caprichos absolutos; pois todos têm o direito de resistir à opressão, e à tirania” ${ }^{56}$ Tais declarações eram uma clara referência ao governo de Pedro I, e continuariam a ser sistematicamente repetidas mais tarde, em plena Regência, na medida em que tanto esta como aquele eram tidos pelos exaltados como governos tirânicos, devendo, então, ser legitimamente derrubados por uma ação revolucionária popular. Os exaltados partiram, inclusive, do discurso para ação, promovendo e tomando parte na maioria das pequenas e grandes revoltas ocorridas em todo o Império em fins do Primeiro Reinado e ao longo do período regencial. O próprio Ezequiel Corrêa dos Santos, redator da Nova Luz Brasileira, participou ativamente da chamada Revolução do 7 de Abril, que levou à queda de Pedro I, e do movimento do povo e tropa de julho de 1831, ambos na corte. ${ }^{57}$

Todavia, a Nova Luz Brasileira prevenia que a revolução constituía um recurso extremo, a ser empregado somente nas situaçóes-limite indicadas. Não deveria, portanto, ser confundida com desordem — o abuso da liberdade pelo povo, em desacordo com as leis. É o que esclarece nos conceitos de Licença e de Anarquia. A primeira é a "Liberdade excessiva do Povo que rompendo os limites da boa ordem, não obedece às Leis como deve, e faz algumas desordens. É o primeiro grau da anarquia”. Esta, por sua vez, é a 
"falta de governo bem regulado: é a pública desobediência às leis, tanto da parte do Povo, como dos seus Magistrados em geral com perturbação e desordem". A mesma idéia é sugerida na definição de Demagogo, "um revolucionário sem justa causa; é aquele que busca sublevar os Povos para maus fins, e com vistas particulares, sem haver despotismo e tirania a combater"; mas, se, neste sentido, o demagogo é um "Cidadão pernicioso, um perturbador", aqui também os absolutistas "mancham no tempo presente com o apelido de — demagogo — os Cidadãos virtuosos, que se animam a combater os abusos, e destruir o absolutismo". ${ }^{58}$

Por fim, um último grupo de definições trata de um outro tipo de questão: a crise econômica e financeira que então assolava o império, decorrente de fatores como o aumento do déficit externo, o desequilíbrio na balança de pagamentos, a queda da produção açucareira, a baixa nos preços dos produtos primários de exportação, os juros elevados, a falência do Banco do Brasil, a livre emissão sem lastro de papel-moeda, a inflação e os sucessivos empréstimos externos. Um dos fatores abordados no dicionário foi exatamente a questão bancária, por conta da recente falência (em 1829) do Banco do Brasil, atribuída por moderados e exaltados aos sucessivos desfalques dados pelo governo para suprir as contas públicas e atender a fins privados. Em sua definição de Banco, a Nova Luz Brasileira apontava, assim, quatro princípios que deveriam guiar a instituição, a fim de garantir sua estabilidade e confiabilidade: primeiro, "afiançar e segurar o [sic] Público da existência, realidade, e infalibilidade de sua moeda, ou dos fundos prometidos e convencionados"; segundo, "não deve emitir de si ou fazer correr mais Notas, do que o valor de seus fundos amoedados"; terceiro, "deve infalivelmente trocar, ou pagar à vista com dinheiro metal corrente as suas Notas"; e quarto, "O Governo não deve ter ingerência, nem autoridade alguma sobre o Banco: nem lhe deve pedir dinheiro algum". 59

O jornal já tocava, assim, em outro elemento fundamental da crise, o problema monetário, o que mais se fazia sentir entre a população da corte, produzido pelas sucessivas falsificações das moedas de cobre e pela emissão descontrolada e sem lastro das mesmas, acarretando sua desvalorização crescente e, logo, a alta do custo de vida. A isto foram dedicadas cinco definições, que procuravam informar sobre o problema. Esclarecia, assim, 
que Tipo da Moeda é "o modelo ou formato dela segundo a lei, o qual exprime o cunho e o seu valor, e demonstra que não é falsa; e de certo modo afiança o peso, a qualidade, e a pureza do metal”. Já Valor Intrínseco ou Interior da Moeda é "a quantidade de metal puro, que entra em uma moe$\mathrm{da}$, e que lhe dá certo valor conforme a opinião dos homens, a respeito dos metais; que eles tomaram para termo de comparação ou medida de seus trabalhos, indústria, e de toda a propriedade". Por outro lado, Valor Extrínseco ou Exterior da Moeda é "um determinado valor que se acrescenta à moeda, ou ao valor do metal; que ela contém; o qual acrescentamento é para descontar a despesa, que se faz em cunhar a moeda". Senhoriagem da Moeda, por sua vez, é "um aumento sobre o valor extrínseco, que por um costume pouco razoável, se lhe ajunta, como espécie de tributo", sendo este acréscimo o que "arruína a natureza do dinheiro". Por fim, Moeda Falsa é "aquela que se cunha, ou fabrica sem autoridade pública; e também aquela que se cunha, e fabrica com esta autoridade, mas que lhe faltam as qualidades e requisitos necessários", havendo, portanto, três espécies de moeda falsa: a primeira se dá quando "pessoas particulares fazem cunhar ocultamente a moeda, sem alterarem nada, nem no valor intrínseco do metal, nem no peso, nem no cunho"; a segunda ocorre quando "ela tem o mesmo cunho, e o mesmo peso da lei; mas que o metal tem mais liga do que convém, e por isso tem menos valor intrínseco"; e a terceira se produz quando "se falsifica o metal ajuntando-se-lhe mais liga, e ao mesmo tempo se diminui o peso da moeda". ${ }^{60}$

Uma última definição aludia à política tributária, uma vez que tanto exaltados como moderados acusavam o governo de Pedro I de impor à população uma pesada carga de impostos, e isto para cobrir o desperdício da receita em gastos excessivos com o sustento de uma corte e de uma burocracia dispendiosas, quando não corruptas, com as despesas de guerras impopulares, como a da Cisplatina e a da sucessão do trono português, e com o pagamento de dívidas para sanar o déficit público. Por conta disto, lembrava o jornal que os Encargos da Sociedade são "unicamente aquelas despesas que se devem fazer $1^{\circ}$ para sua conservação: $2^{\circ}$ para sua segurança: $3^{\circ}$ para cômodo e felicidade geral de todos os Cidadãos"; tudo o mais seria supérfluo, de modo que "Tirar do Cidadão mais do que se precisa para as ditas três coisas, é furto feito à sua propriedade, é um atentado". ${ }^{61}$ 


\section{A título de conclusão}

Como já dito, o dicionário cívico doutrinário da Nova Luz Brasileira não esgota o ideário do jornal e, tampouco, dos exaltados. Mas constitui, sem dúvida, uma singular evidência do desenvolvimento de um novo vocabulário político e das transformaçóes semânticas em curso (como indicam os significados peculiares atribuídos a vários termos), e, logo, da importância adquirida por esta linguagem no contexto de definição identitária das facções políticas e de gestação da esfera pública. Mais do que isso, revela o empenho dos exaltados em difundir essa linguagem e instruir a opinião pública nos novos princípios. Tanto que outras iniciativas semelhantes, ainda que de dimensões mais reduzidas, foram efetuadas na mesma época, como o dicionário produzido em 1831 pelo periódico $O$ Exaltado, contendo a explicação de vinte e três conceitos relativos aos fundamentos e tipos de governo e de soberania. ${ }^{62}$

Uma das características mais marcantes dos jornais exaltados (compartilhada, em menor grau, pelas demais facçôes) era justamente a preocupação em esclarecer, em iluminar o público-leitor; intenção por vezes manifesta no próprio título das publicações, como a Nova Luz Brasileira. É precisamente este o objetivo de seu dicionário, conforme declarou de início: "COMO o nosso desejo é apresentar luzes a quem está nas trevas do pouco saber, oferecemos aos leitores várias explicações de termos, e frases, que alguns talvez ignorem". ${ }^{63}$ Ao procurar instruir o público nos novos princípios políticos, tornando-o conhecedor de seus direitos e estimulando sua consciência política, a Nova Luz Brasileira buscava formar o verdadeiro cidadão. Realizava, assim, uma pedagogia política do cidadão, uma ação doutrinária visando educar os indivíduos para a participação política, de acordo, é claro, com as concepções exaltadas. E, nesta missão, almejava atingir um público mais amplo, que abrangesse não só a elite intelectual, mas, em especial, aqueles indivíduos que, embora alfabetizados, não tinham acesso às grandes obras do pensamento ilustrado. Procurava atingir até mesmo o público não alfabetizado, que entrava em contato com a cultura política liberal por meio dos mecanismos diversos de circulação oral das idéias, típicos de uma sociedade fortemente marcada pela oralidade. ${ }^{64}$ Para 
isso, era preciso que os jornais se fizessem entender por esse público, e o primeiro passo era a própria linguagem utilizada. Procuraram, assim, empregar uma linguagem simples, objetiva, livre da complexidade dos tratados políticos e filosóficos. Como fazia a Nova Luz Brasileira, que justificava sua linguagem direta, virulenta, avessa às convençôes discursivas de civilidade, em nome do dever de falar a verdade, e porque, afinal, "Nós queremos ser entendidos rapidamente pela mais rude inteligência sem reflexão" ${ }^{65}$ Como se deu este entendimento, ou melhor, como esta linguagem foi apropriada, esta é uma outra história que ainda está por ser contada.

\section{Notas}

${ }^{1}$ Sobre as diversas tendências, as perspectivas de análise e o percurso historiográfico da história intelectual, ver DARNTON, Robert. O beijo de Lamourette: mídia, cultura e revolução. São Paulo: Companhia das Letras, 1990, capítulos 10 e 11; KELLEY, Donald R. Horizons of intellectual history: retrospect, circumspect, prospect. In: IDEM (ed.). The history of ideas: canon and variations. Rochester: University of Rochester Press, 1990; e FALCON, Francisco. História das idéias. In: CARDOSO, Ciro Flamarion, e VAINFAS, Ronaldo (org.). Dominios da história: ensaios de teoria e metodologia. Rio de Janeiro: Campus, 1997. As recentes reformulações no âmbito da história das idéias e suas estreitas relaçōes com a nova história política são ainda sublinhadas por WINOCK, Michel. As idéias políticas. In: RÉMOND, René (org.). Por uma história política. Rio de Janeiro: Editora UFRJ/ Fundação Getulio Vargas, 1996. Uma crítica mordaz e bem fundamentada aos postulados clássicos da história intelectual encontra-se em CHARTIER, Roger. $A$ história cultural: entre práticas e representaçôes. Lisboa: Difel/ Bertrand Brasil, 1990, capítulo I.

${ }^{2}$ Cf. POCOCK, John Greville Agard. Politics, language and time: essays on political thought and history. Chicago/ Londres: The University of Chicago Press, 1989, capítulo 1; Idem, The concept of a language and the métier d'historien: some considerations on practice. In: PAGDEN, Anthony R. (org.), The languages of political theory in early-modern Europe. Cambridge/ Nova York/ Melbourne: Cambridge University Press, 1990, sobretudo pp. 24 e 37; e SKINNER, Quentin, As fundaçôes do pensamento político moderno. São Paulo: Companhia das Letras, 1996, em especial pp. 12 e 620. Preocupaçōes semelhantes, na linha da história dos conceitos e da história conceitual do político, encontra-se em KOSELLECK, Reinhart. "Uma história dos conceitos: problemas teóricos e práticos". In: Estudos Históricos, v. 5, no 10. Rio de Janeiro: CPDOC — Fundação Getulio Vargas, 1992; e ROSANVALLON, Pierre. "Por uma história conceitual do político (nota de trabalho)". In: Revista Brasileira de História, v. 15, nº 30. São Paulo: ANPUH/ Contexto, 1995.

${ }^{3}$ CARVALHO, José Murilo de. "História intelectual no Brasil: a retórica como chave de leitura”. In: Topoi: revista de história, no ${ }^{2}$. Rio de Janeiro: 7 Letras, setembro de 2000, pp. 
123-127. Uma síntese da produção brasileira na área encontra-se também em FALCON, Francisco, ob. cit., pp. 122-125, que igualmente ressalta o fato de "não existir entre nós uma verdadeira tradição historiográfica no âmbito da história das idéias e de sermos ainda um tanto pobres no campo da história intelectual".

${ }^{4}$ Para uma ampla e precisa análise da cultura política da Independência e dos termos do vocabulário de sua linguagem política, ver NEVES, Lúcia Maria Bastos Pereira das. Corcundas, constitucionais e pés-de-chumbo: a cultura política da Independência, 1820-1822. 2 v. Tese de Doutorado apresentada ao Programa de Pós-Graduação em História da USP. São Paulo, 1992, especialmente v. I, capítulo 2.

${ }^{5}$ Sobre Cipriano Barata, ver, entre outros trabalhos, MOREL, Marco. Cipriano Barata na Sentinela da Liberdade. Salvador: Academia de Letras da Bahia/ Assembléia Legislativa do Estado da Bahia, 2001.

${ }^{6}$ Cf. LENHARO, Alcir. As tropas da moderação (o abastecimento da Corte na formação política do Brasil - 1808-1842). Rio de Janeiro: Secretaria Municipal de Cultura, Turismo e Esportes - Departamento Geral de Documentação e Informação Cultural — Divisão de Editoração, 1993 (2ª ed.).

${ }^{7}$ Sobre o projeto político exaltado, ver BASILE, Marcello Otávio Neri de Campos. Anarquistas..., ob. cit., capítulos II e III; e IDEM. Ezequiel Corrêa dos Santos: um jacobino na corte imperial. Rio de Janeiro: Fundação Getulio Vargas, 2001, 1ํ e 2o capítulos.

${ }^{8}$ Para o conceito de esfera pública, ver HABERMAS, Jürgen. Mudança estrutural da esfera pública: investigaçôes quanto a uma categoria da sociedade burguesa. Rio de Janeiro: Tempo Brasileiro, 1984. Sobre o processo de formação da esfera pública na Corte, ver MOREL, Marco. La formation de l'espace publique moderne a Rio de Janeiro (1820-1840): opinion, acteurs et sociabilité. $2 \mathrm{v}$. Tese de Doutorado apresentada à UFR d'Histoire — Université de Paris I (Pantheon Sorbonne). Paris, 1995; NEVES, Lúcia Maria Bastos Pereira das, ob. cit., v. I; e BASILE, Marcello Otávio Neri de Campos. Anarquistas..., ob. cit., capítulo VIII.

${ }^{9}$ Apud SOUSA, Octavio Tarquinio de. História dos fundadores do Império do Brasil, v. VII — Diogo Antônio Feijó. Rio de Janeiro: José Olympio, 1957, p. 182.

${ }^{10}$ Exemplo de arbitrariedade das mais abomináveis, segundo o jornal, é a Proscrição $\boldsymbol{e}$ Deportação, que, consistindo na "expulsão violenta e repentina de um Cidadão para fora de sua Pátria sem forma alguma de justiça”, era um recurso dos tiranos para "suplantar as Leis, sufocar o descontentamento público, e afogar a energia dos bons Cidadãos". Nova Luz Brasileira, no 23 - 26/2/1830.

${ }^{11}$ A de Sagrado e a de Inviolável. O primeiro é "aquilo que se reputa puro, santo, com qualidades Divinas, e não profanas”, sendo, então, só "aplicável às coisas Divinas”; a definição era uma crítica àqueles que "abusam da palavra — sagrado — aplicando-a mesmo a tiranos". O mesmo se dava com o segundo termo, que sendo "aquilo que ninguém deve tocar, nem profanar, nem ofender, nem macular", referia-se mais aos tribunos do povo romanos do que aos déspotas. Ibidem, nos $54-22 / 6 / 1830$, e $55-25 / 6 / 1830$, respectivamente. 


\section{$124 \cdot$ T о Р О I}

${ }^{12}$ As três primeiras definiçôes estão todas em ibidem, $\mathrm{n}^{\circ} 17-5 / 2 / 1830$; a quarta no $\mathrm{n}^{\circ}$ 18 - 9/2/1830; a quinta, a sexta e a sétima no $\mathrm{n}^{\circ} 19-12 / 2 / 1830$; a oitava no $\mathrm{n}^{\mathrm{o}} 20-$ 16/2/1830; a nona no oㅜ $51-8 / 6 / 1830$; e a décima no no $55-25 / 6 / 1830$. De forma semelhante, Moraes Silva define Despotismo como "Autoridade, poder absoluto. \$. Abuso do poder contra a razão, contra a Lei; excesso de direito, que faz o que governa", ao passo que Tyranía significaria "Império, governo do tirano" e, em sentido figurado, "Ação desumana, cruel, injusta", e Tyrano "O príncipe que é único, e despótico; o que usurpou o governo. [...] O que governa mal contra as leis, privando arbitrariamente os seus vassalos dos bens, da liberdade civil, das vidas, e honras". SILVA, Antonio de Moraes. Diccionario da lingua portugueza recopilado dos vocabularios impressos até agora, e nesta segunda edição novamente emendado, e muito accrescentado. Rio de Janeiro: Oficinas da S. A. LithoTypographia Fluminense, 1922 (fac-símile da 2aㅡ ed., de 1813), p. 598 do t. I e pp. 818819 do t. II.

${ }^{13}$ Nova Luz Brasileira, $\mathrm{n}^{\text {os }} 17$ - 5/2/1830, 16 - 3/2/1830, 58 - 9/7/1830, 18 - 9/2/ 1830, 22 - 23/2/1830 e 59 - 13/7/1830, respectivamente. Moraes Silva só apresenta verbete para Legitimidade, definido, sem conotação política, como "A qualidade de ser legítimo" (sendo Legítimo o que está "Conforme as Leis”, "Genuíno, não espúrio”). Ob. cit., t. II, p. 212.

${ }^{14}$ Um governo absoluto, segundo o jornal, poderia ser de fato, mas nunca de direito. Conforme esclarecia, De Direito é "aquilo que é conforme as regras da eqüidade; conforme o que mandam as leis da razão, da justiça, e da natureza. (ainda que se não esteja de posse de causa.)", enquanto De fato é “o que está praticado, e posto em ação, e execução, sem se tomar em consideração o - direito". Assim, De Fato e de Direito é o mesmo que "possuir com segurança, lograr e dispor [ilegível] por obras e ações públicas, de uma coisa que por todos os modos nos pertence: é ter direito de governar a coisa pacificamente". Nova Luz Brasileira, no $49-28 / 5 / 1830$.

${ }^{15}$ Uma fonte registra que a notícia da queda de Carlos X foi "a faísca elétrica que despertou o Brasil", visto que "seu governo apresentava muitos pontos de semelhança com o de D. Pedro”. REVOLUÇÃO DE 7 DE ABRIL DE 1831. Acontecimentos dos dias 6 e 7 de Abril de 1831. Origens da abdicação de D. Pedro 1‥ P. 25. Biblioteca Nacional - Divisão de Manuscritos. I-32, 6, 24. De fato, a partir daí, o discurso exaltado contra Pedro I radicaliza-se, a todo instante comparando-o a Carlos X e lembrando o trágico destino que este tivera.

${ }^{16}$ Ver a respeito, Nova Luz Brasileira, no 152 - 9/7/1831, por exemplo.

${ }^{17} \mathrm{O}$ número acusado foi o 154 , de 20 de julho de 1831, onde dizia que a Soberania Nacional poderia declarar-se "mui legal, e pacificamente pela federação do Equador sem guerra intestina”. Em mais um jogo de retórica, o jornal negou que, no trecho acusado, propusesse a instauração da República, mas, ao mesmo tempo, declarava que, se isto fosse verdade, "não tinha crime algum", que a república democrática "em nossa opinião é coisa boa, e muito boa" e que "a Soberania Nacional pode, se assim o entender proclamar tranqüilamente a República democrática, e federal, ou a federação do Equador”. Ibidem, $\mathrm{n}^{\mathrm{o}} 165-1 / 9 / 1831$. 
${ }^{18}$ Referência aos periódicos moderados Aurora Fluminense, de Evaristo da Veiga, O Farol Paulistano, do regente José da Costa Carvalho, e $O$ Independente, então dirigido por Joaquim José Rodrigues Torres, e também ao cônego Januário da Cunha Barbosa.

${ }^{19}$ Nova Luz Brasileira, no 174 - 24/9/1831. Sobre a defesa do governo republicano pela ampla maioria dos jornais exaltados da Corte, em contraposição às concepções monarquistas das folhas moderadas, ver BASILE, Marcello Otávio Neri de Campos. Anarquistas..., ob. cit., capítulo II, pp. 71-78.

${ }^{20}$ Nova Luz Brasileira, $\mathrm{n}^{\mathrm{os}} 17$ - 5/2/1830 (primeira definição), 25 - 5/3/1830 (segunda e terceira), 26 - 9/3/1830 (quarta a sétima) e 27 - 12/3/1830 (oitava). De forma semelhante, Moraes Silva define Ministério como "O ofício dos Ministros de Estado, ou do Evangelho" e também "Os Ministros de Estado de qualquer Nação". Assembléia tem apenas o sentido de "Junta de pessoas convocadas para divertimento, e convivência; ou para consultarem sobre negócio sério". Já Legislativo é o "Que respeita à Legislação, a dar Leis", mas o exemplo dado mostra bem o referencial de Antigo Regime que ainda fundamentava o termo: "o poder legislativo reside no Soberano, ou é Direito Majestático". Delegado, por sua vez, possui somente o sentido de particípio passado do verbo delegar, enquanto os verbetes Executivo e Judiciário não contêm definição alguma relativa aos poderes homônimos do Estado. SILVA, Antonio de Moraes, ob. cit., p. 302 do t. II, p. 207 do t. I, p. 212 do t. II, p. 524 do t. I, p. 795 do t. I e p. 192 do t. II, respectivamente.

${ }^{21}$ É bem ilustrativa quanto a isso a Carta aos senhores eleitores da provincia de Minas Gerais, de Bernardo Pereira de Vasconcellos, onde o político mineiro emprega ambiguamente o termo pátria para se referir tanto à sua província, como ao país, chamando Minas Gerais de "nossa Pátria” e o Brasil de "comum Pátria”. In: VASCONCELOS, Bernardo Pereira de. Bernardo Pereira de Vasconcelos. Organização, introdução e notas de José Murilo de Carvalho. São Paulo: Editora 34, 1999, pp. 61, 67, 189 e 190, por exemplo. Sobre a força do patriotismo provincial e a inexistência de uma identidade nacional efetiva até, pelo menos, a Guerra do Paraguai, cf. CARVALHO, José Murilo de. Cidadania no Brasil: o longo caminho. Rio de Janeiro: Civilização Brasileira, 2001, pp. 76-80; e Idem. "Cidadania: tipos e percursos”. In: Estudos Históricos, v. 9, nº 18. Rio de Janeiro: CPDOC Fundação Getulio Vargas, 1996, pp. 342, 350 e 351.

${ }^{22}$ As três primeiras definições acham-se, respectivamente, em Nova Luz Brasileira, $\mathrm{n}^{\mathrm{os}} 14$ - 26/1/1830, 21 - 19/2/1830 e 13 - 22/1/1830; a quinta no no $16-3 / 2 / 1830$; a quarta e a sexta no no $15-29 / 1 / 1830$. Conotações diversas, bem ao estilo do Antigo Regime, tinham as definições dadas no dicionário de Moraes Silva para os vocábulos Estado (em sentido político, "Classe de Cidadãos: v. g. o Estado da Nobreza, do Clero, do Povo"; "Os Estados; i. é, os tres Estados da Nação"), Nação ("A gente de um país, ou região, que tem Língua, Leis, e Governo à parte"; "Raça, casta, espécie”) e Pátria ("A terra donde alguém é natural”). SILVA, Antonio de Moraes, ob. cit., pp. 769-770 do t. I, p. 332 do t. II, e p. 412 do t. II, respectivamente.

${ }^{23}$ Ambas as definições encontram-se em Nova Luz Brasileira, no 21 - 19/2/1830. 
${ }^{24}$ Nova Luz Brasileira, n ${ }^{\mathrm{os}} 16-3 / 2 / 1830,23-26 / 2 / 1830$ e, para as duas últimas definições, $24-2 / 3 / 1830$. Os verbetes Imprescriptivel e Inalienável do dicionário Moraes Silva (ob. cit., t. II, pp. 138 e 140) não contêm conotações políticas. Já o de Homem (t. II, p. 117) possui alguns significados que, mais uma vez, denotam uma matriz de Antigo Regime, como "Ter homem; i. é, protetor, que auxilia com favor, ou fazenda"; "Homem del-Rei; i. é, seu Vassalo"; "Homem de Deus; santo, virtuoso"; e "Homem bom; de bem, fidalgo, nobre".

${ }^{25}$ Nova Luz Brasileira, no 11 - 15/1/1830 (grifos meus).

${ }^{26}$ SILVA, Antonio de Moraes, ob. cit., t. II, p. 481.

${ }^{27}$ Aurora Fluminense, oㅜ 553 - 7/11/1831.

${ }^{28}$ MATTOS, Ilmar Rohloff de. O Tempo Saquarema: a formação do Estado imperial. São Paulo: HUCITEC, 1990 (2 ed.), pp. 125 e 259. A mesma concepção encontra-se na Europa entre séculos XVII e XIX. Ver a respeito, HILL, Christopher. Os pobres e o povo na Inglaterra do século XVII. In: KRANTZ, Frederick (org.). A outra história: ideologia e protesto popular nos séculos XVII a XIX. Rio de Janeiro: Jorge Zahar, 1990.

${ }^{29}$ Entendendo que a questão do tráfico negreiro já havia sido resolvida pelo tratado anglobrasileiro de 1826 (que previa a abolição deste comércio a partir de 1830), a proposta emancipacionista apresentada pelo jornal procurava dar um passo a mais, assemelhandose à Lei do Ventre-Livre, promulgada quarenta anos depois. Propunha, assim, uma lei que tornasse livres os filhos de escravos nascidos desde então, mas de modo que ficassem adscritos à gleba até completarem trinta anos de idade. Seria este "o melhor meio de acabar com a escravidão interna, sem qualquer prejuízo da lavoura, e dos Proprietários d'escravos". Igualmente sugeria que as irmandades e ordens religiosas acumulassem anualmente um pecúlio, destinado a libertar os cativos de boa conduta. Nova Luz Brasileira, $\mathrm{n}^{\circ}$ 132 - 19/4/1831. Se o jornal não se mostrou aqui tão radical como em outras medidas propostas, cumpre notar que, ainda assim, suas idéias estavam à frente das dos demais grupos políticos da época, que se mostraram bem mais cautelosos, quando não totalmente omissos, a este respeito. Maiores detalhes em BASILE, Marcello Otávio. Ezequiel Corrêa dos Santos..., ob. cit., 2o capítulo, pp. 66-71.

${ }^{30}$ Nova Luz Brasileira, no ${ }^{\circ} 16-3 / 2 / 1830$.

${ }^{31}$ Conforme esclarecia o jornal em sua definição de Virtude, provavelmente apropriada de Montesquieu, "Falando em geral, é toda a ação, ou qualquer coisa praticada em benefício e utilidade do Gênero Humano", e, "em particular, é qualquer ação praticada em proveito da Pátria”. Nova Luz Brasileira, no $22-23 / 2 / 1830$.

${ }^{32}$ Ver os textos dos revolucionários franceses sobre o papel das mulheres (contra e a favor da igualdade de direitos entre os sexos) em BADINTER, Elisabeth (org.). Palavras de homens (1790-1793). Rio de Janeiro: Nova Fronteira, 1991. Sobre a luta das mulheres francesas pela conquista da cidadania plena, e a discriminação por elas sofrida na época da Revolução, vide GERHARD, Ute. Sobre a liberdade, igualdade e dignidade das mulheres: o direito 'diferente' de Olympe de Gouges e FIORINO, Vinzia. Ser cidadã francesa: uma reflexão sobre os principios de 1789. In: BONACCHI, Gabriella, e GROPPI, Angela (org.). 
O dilema da cidadania: direitos e deveres das mulheres. São Paulo: Editora da Universidade Estadual Paulista, 1995, onde se acha reproduzida em apêndice a Declaração de Gouges. A visão androcêntrica da Ilustração é analisada por DEL PRIORI, Mary, "No século das luzes, mulheres à sombra... — a condição feminina e a revolução francesa". In: Acervo, v. 4, no 1 . Rio de Janeiro: Ministério da Justiça — Arquivo Nacional, janeiro-junho de 1989. Sobre a relativa exclusão feminina da esfera pública burguesa nos séculos XVIII e XIX, e formas alternativas de participação da mulher, cf. CALHOUN, Craig (org.), Habermas and the public sphere. Cambridge/ Massachusetts/ Londres: Massachusetts Institute of Technology, 1996 ( $4^{\mathrm{a}}$ ed.).

${ }^{33}$ Sustentava, assim, que o engajamento feminino nas questōes públicas justificava-se e se impunha na medida em que "a Pátria, os Direitos, Liberdade, e garantias, pertencem a todos sem exceção", e a abstenção da mulher nesta questão implicaria, portanto, em sua anulação social, visto que o "vilipêndio, e a nenhuma representação na sociedade é o dote, é a sorte que espera o belo sexo no Brasil, se ele não se interessar calorosamente pela Independência, e Constituição". Nova Luz Brasileira, nos 22 e 7 -23/2/1830 e 31/12/1829. Ver a respeito, BASILE, Marcello Otávio. Ezequiel Corrêa dos Santos..., ob. cit., 2o capítulo, pp. 54-56.

${ }^{34}$ Nova Luz Brasileira, nํ58 - 9/7/1830.

${ }^{35} \mathrm{Ibidem}, \mathrm{n}$ ㅇ 57 - 6/7/1830 e, para o último conceito, 58 - 9/7/1830. No verbete Direito, Moraes Silva apenas menciona o "direito de Cidadãos", sem esclarecer o que seria ou quais seriam esses direitos. Já o verbete Garantia não possui significados políticos. SILVA, Antonio de Moraes, ob. cit., p. 621 do t. I e p. 78 do t. II.

${ }^{36}$ Nova Luz Brasileira, no 22 - 23/2/1830. Como se poderia imaginar, Moraes Silva (ob. cit., t. II, p. 517) limita-se à explicação convencional do termo, no sentido de bens materiais possuídos e de atributo, qualidade.

${ }^{37}$ Nova Luz Brasileira, $\mathrm{n}^{\circ}$ 56 - 2/7/1830. Os verbetes Súbdito e Vassalo, de Moraes Silva, trazem os significados ainda hoje usuais destas palavras (ob. cit., t. II, pp. 730 e 834-835). ${ }^{38}$ Sobre estas três vertentes da cidadania, cf. CARVALHO, José Murilo de. Virtus in medio. Trabalho apresentado no colóquio interdisciplinar "Virtudes e interesses no pensamento político moderno e contemporâneo", organizado pelos programas de pós-graduação em História e Filosofia da Universidade Federal de Minas Gerais, entre os dias 2 e 4 de setembro de 1998, pp. 1 e 2.

${ }^{39}$ MARSHALL, T. H. Cidadania, Classe Social e Status. Rio de Janeiro: Zahar, 1967, capítulo III, pp. 63-74.

${ }^{40}$ COSTA, Emília Viotti da. Da Monarquia à República: momentos decisivos. São Paulo: Brasiliense, s/d. (5a ed.), p. 135.

${ }^{41}$ Nova Luz Brasileira, $\mathrm{n}^{\circ} 45-14 / 5 / 1830$.

${ }^{42}$ Ibidem, nos $31-26 / 3 / 1830$ (primeiro e último conceitos), $30-23 / 3 / 1830$ (segundo) e 29 - 20/3/1830 (terceiro). Em Moraes Silva, Aristocracia é definida apenas como "Forma de governo, em que os Direitos Majestáticos residem em uns poucos de homens os mais nobres por merecimento, ou nascimento". Já Fidalgo, Nobre e Nobreza são defini- 
dos, sem conotações críticas, como categorias sociais dotadas de distinções reais, ao passo que para senhor feudal não há verbete. Ob. cit., p. 179 do t. I, e pp. 30 e 344 do t. II.

${ }^{43}$ Nova Luz Brasileira, no 32 - 30/3/1830.

${ }^{44}$ Cf. BASILE, Marcello Otávio Neri de Campos. "A reforma agrária cidadã: o Plano do Grande Fateusim Nacional'. In: Estudos Sociedade e Agricultura, no 10. Rio de Janeiro: CPDA - Universidade Federal Rural do Rio de Janeiro, abril de 1998; e Idem. Ezequiel Corrêa dos Santos..., ob. cit., capítulo III, pp. 105-114.

${ }^{45}$ Nova Luz Brasileira, nos $45-14 / 5 / 1830,47-21 / 5 / 1830$ e $29-20 / 3 / 1830$.

${ }^{46}$ Nova Luz Brasileira, nos $40-27 / 4 / 1830,47-21 / 5 / 1830$ e 43 - 7/5/1830, respectivamente. Moraes Silva (ob. cit., t. II, p. 244) registra o termo Machiavellísta, como a "Pessoa que segue as artes, e máximas de Machiavello", explicando, em seguida, que Machiavello, além do "célebre Político Italiano", em sentido figurado queria dizer o "homem que vai a seus fins sem respeitar a honestidade, ou justiça dos meios".

${ }^{47}$ Obediência Cega e Passiva, por sua vez, era definida como "a prática de obedecer calado, com os olhos fechados, a torto, e a direito, como se o homem fosse autômato, e máquina sem razão, nem sentidos"; acrescentava o jornal que esta espécie de servidão, "própria dos escravos, é uma pedra fundamental da doutrina dos abomináveis Jezuítas". Nova Luz Brasileira, no 28 - 16/3/1830.

${ }^{48}$ Ibidem, nos $47-21 / 5 / 1830$ (primeira e última definiçōes), $43-7 / 5 / 1830$ (segunda e terceira) e $44-11 / 5 / 1830$ (quarta).

${ }^{49}$ Ibidem, no $27-12 / 3 / 1830$.

${ }^{50}$ Ibidem, $\mathrm{n}^{\mathrm{os}} 41-30 / 4 / 1830$ (duas primeiras definiçôes) e $42-4 / 5 / 1830$.

${ }^{51}$ Ibidem, nos 34 - 6/4/1830, 35 - 9/4/1830, 37 - 16/4/1830 (terceira e quarta definições), 39 - 23/4/1830 e $44-11 / 5 / 1830$. A apreciação positiva das organizações secretas transparece ainda na definição de Clube, que é um "ajuntamento reservado de pessoas que sem faculdade do Governo, tratam de alguma coisa extraordinária; por isso sempre se interpreta que é para mal: contudo é preciso notar que, às vezes, os ajuntamentos não são clubs; antes se dirigem para coisas muito boas". Ibidem, no 33 - 2/4/1830.

52 Ibidem, $\mathrm{n}^{\text {os }} 34-6 / 4 / 1830,20-16 / 2 / 1830,21-19 / 2 / 1830$ (terceira e quarta definições) e $20-16 / 2 / 1830$.

${ }^{53}$ Ibidem, no 58 - 9/7/1830. Para Moraes Silva (ob. cit., t. II, p. 706), Soberania vinha a ser simplesmente "A qualidade de ser soberano, e os direitos anexos a ela. \$. Imperiosidade, altiveza”.

${ }^{54}$ Cf. LOCKE, John. Segundo tratado sobre o governo civil - e outros escritos: ensaio sobre a origem, os limites e os fins verdadeiros do governo civil. Petrópolis: Vozes, 1994, capítulos XI e XIX; e ROUSSEAU, Jean-Jacques. O contrato social. São Paulo: Martins Fontes, 1989, capítulos I e II do Livro II.

${ }^{55}$ Nova Luz Brasileira, nำ $50-4 / 6 / 1830$.

${ }^{56}$ Ibidem, $\mathrm{n}^{\mathrm{os}} 52-11 / 6 / 1830,51-8 / 6 / 1830$ e (para os dois últimos itens) $20-16 /$ 2/1830. Moraes Silva define Rebellião em seu sentido usual, como "Levantamento dos vassalos contra seu Soberano" (ob. cit., t. II, p. 559), não constando a palavra insurreição. 
${ }^{57}$ Sobre as revoltas ocorridas na Corte em 1831, ver BASILE, Marcello Otávio Neri de Campos. Anarquistas..., ob. cit., capítulos VI e VII; e Idem. Ezequiel Corrêa dos Santos, ob. cit., 3o capítulo.

${ }^{58}$ Nova Luz Brasileira, $\mathrm{n}^{\text {os }} 18$ - 9/2/1830, 19 - 12/2/1830 e 33 - 2/4/1830. Para Moraes Silva, Licença é o "abuso da liberdade, excesso de direito, quebra da Lei”, sendo Anarchia a "Falta de Chefe, de Soberano, de Regente. $\$$ fig. A desordem civil, que procede dessa falta" (ob. cit., t. II, p. 223, e t. I, p. 129).

${ }^{59}$ Nova Luz Brasileira, no 28 - 16/3/1830.

${ }^{60}$ Ibidem, nos $53-15 / 6 / 1830$ e (para o último conceito) $54-22 / 6 / 1830$.

${ }^{61}$ Ibidem, no $22-23 / 2 / 1830$.

${ }^{62}$ Cf. BASILE, Marcello Otávio Neri de Campos. Anarquistas..., ob. cit., capítulo IV, pp. 160-166.

${ }^{63}$ Nova Luz Brasileira, no 11 - 15/1/1830.

${ }^{64}$ Sobre essa cultura da oralidade na Corte, ver NEVES, Lúcia Maria Bastos Pereira das, ob. cit., v. I, capítulo 1; e MOREL, Marco. La formation..., ob. cit., v II, capítulo VII. Sobre as especificidades da oralidade, cf. ONG, Walter J. Oralidade e cultura escrita: a tecnologização da palavra. Campinas: Papirus, 1998.

${ }^{65}$ Ibidem, no $10-12 / 1 / 1830$.

\section{Resumo}

$O$ artigo ressalta as linguagens politicas, no sentido de John Pocock e Quentin Skinner, como instrumento de análise para o estudo dos projetos politicos concorrentes no Brasil, particularmente na primeira metade do século XIX. Analisa, assim, a linguagem politica radical desenvolvida em fins do Primeiro Reinado e durante o período regencial pelos chamados "liberais exaltados", tomando como exemplo as definições doutrinárias dadas para um conjunto de cento e oito conceitos de significação politica produzidos pelo principal jornal exaltado da corte do Rio de Janeiro, a Nova Luz Brasileira, publicado entre 1829 e 1831.

\section{Abstract}

The paper emphasizes the importance of political languages, according to John Pocock and Quentin Skinner, as an analytical instrument to study the contestant political projects in Brazil, especially in the first half of the nineteenth century. So, it analyses 
$130 \cdot$ Tоро I

the radical political language developed by the called "liberais exaltados" in the end of the First Reign and during the Regency period. It is taken as example the doctrinaire definitions given for a set of one hundred and eight concepts of political meaning produced by Nova Luz Brasileira, the main "exaltado" newspaper from the Rio de Janeiro court, published between 1829 and 1831. 